\title{
Lessons on Evolution from the Study of Edaphic Specialization
}

\author{
Nishanta Rajakaruna ${ }^{1,2,3}$ \\ ${ }^{1}$ Biological Sciences Department, California Polytechnic State University, San Luis Obispo, CA 93407, USA \\ ${ }^{2}$ Unit for Environmental Sciences and Management, North-West University, Private Bag X6001, \\ Potchefstroom 2520, South Africa \\ ${ }^{3}$ Author for Correspondence; e-mail: nrajakar@calpoly.edu
}

\begin{abstract}
Plants adapted to special soil types are ideal for investigating evolutionary processes, including maintenance of intraspecific variation, adaptation, reproductive isolation, ecotypic differentiation, and the tempo and mode of speciation. Common garden and reciprocal transplant approaches show that both local adaptation and phenotypic plasticity contribute to edaphic (soil-related) specialization. Edaphic specialists evolve rapidly and repeatedly in some lineages, offering opportunities to investigate parallel evolution, a process less commonly documented in plants than in animals. Adaptations to soil features are often under the control of major genes and they frequently have direct or indirect effects on genes that contribute to reproductive isolation. Both reduced competitiveness and greater susceptibility to herbivory have been documented among some edaphic specialists when grown in 'normal' soils, suggesting that a high physiological cost of tolerance may result in strong divergent selection across soil boundaries. Interactions with microbes, herbivores, and pollinators influence soil specialization either by directly enhancing tolerance to extremes in soil conditions or by reducing gene flow between divergent populations. Climate change may further restrict the distribution of edaphic specialists due to increased competition from other taxa or, expand their ranges, if preadaptations to drought or other abiotic stressors render them more competitive under a novel climate.
\end{abstract}

Keywords Ecological Speciation · Edaphic Endemism · Harsh Environments · Cost of Tolerance $\cdot$ Serpentine $\cdot$ Metal Tolerance $\cdot$ Parallel Speciation · Geobotany $\cdot$ Plant-Soil Relations $\cdot$ Local Adaptation

"The red-rock forest may seem hellish to us, but it is a refuge to its flora...it is the obdurate physical (and chemical) adversity of things such as peridotite bedrock which often drives life to its most surprising transformations" (Wallace, 1983)

\section{Introduction}

Over a century and a half after Darwin's On the Origin of Species, there is little doubt that ecological adaptation plays a crucial role in the diversification of species (Nosil, 
2012). The study of ecological speciation marks a central theme in evolutionary biology, with a major focus on understanding the role of adaptation in reproductive isolation (Baack et al., 2015) and species divergence (Schemske, 2010).

Plants found on 'extreme' soils, those characterized by unusual chemical $(\mathrm{pH}$, ionic strength, nutrients, or heavy metals) or physical conditions (soil moisture, temperature, texture, structure, or depth), provide model systems to examine the role of edaphic (soilrelated) adaptation in ecological speciation (Rajakaruna, 2004; Kay et al., 2011) and adaptive radiation (Ellis \& Weis, 2005; Paun et al., 2016; Shimizu-Inatsugi et al., 2016). The landmark papers "Evolution in closely adjacent plant populations" (Antonovics, 2006 and references therein) focused on the evolution of metal tolerance in the grasses Anthoxanthum odoratum and Agrostis tenuis on mine tailings in Europe. These classic papers, along with early studies of ecotypes on western North American serpentine soils (Anacker, 2014 and references therein), illustrated how strong selection can maintain distinct sub-populations in the face of gene flow, highlighting three key lessons from edaphic specialization pertinent to evolution: first, edaphic transitions often have direct or indirect effects on reproductive isolation between ecologically-divergent populations (Christie \& Macnair, 1987; Wright et al., 2013), suggesting a link between adaptation and speciation; second, some populations can evolve (or lose) tolerance to edaphic conditions rapidly and with relative ease, suggesting that major gene loci (i.e., loci with large phenotypic effects) could be driving adaptive evolution (Macnair, 1983; Bratteler et al., 2006, 2006; Lowry et al., 2012); and third, populations within some species can independently evolve tolerance to edaphic conditions (i.e., tolerance evolves multiple times within a species), suggesting a tendency towards parallel evolution (Rajakaruna \& Whitton, 2004; Ostevik et al., 2012; Roda et al., 2013). Edaphic specialists, especially plants growing in ultramafic (Harrison \& Rajakaruna, 2011; Anacker, 2014), gypsum (Moore et al., 2014; Escudero et al., 2015; Bolukbasi et al., 2016), mine tailing (Ernst, 2006), seleniferous (Schiavon \& Pilon-Smits, 2017), and saline (Saslis-Lagoudakis et al., 2014; Cheeseman, 2015) habitats, are now at the forefront of plant evolutionary research, providing model systems for exploring factors and mechanisms driving evolutionary processes from the species to community level (Cheplick, 2015).

In this review, I highlight studies of edaphic specialists from serpentine outcrops, saline soils, gypsum and other carbonate deposits, and heavy metal-rich mine tailings, and explore such questions as:

- How do edaphic endemics evolve (i.e., what are the major pathways to edaphic specialization)?

- Are edaphic endemics new or old species?

- How does adaptation contribute to reproductive isolation?

- Is the transition to edaphic endemism directional, and are edaphic endemics evolutionary dead-ends?

- Does parallel evolution of traits conferring adaptations and reproductive isolation occur frequently in edaphic specialists?

- How does tolerance to edaphic extremes influence competitiveness in 'normal' soils, i.e., what is the cost of tolerance?

- Do interactions with herbivores or microbes drive the evolution of edaphic specialization?

- Are edaphic specialists more or less sensitive to climate change? 
- What is the genetic basis of edaphic specialization and speciation? Is there evidence for horizontal gene flow conferring edaphic adaptation or for genetic similarity among the mechanisms used by different species under any given edaphic stress?

Finally, I outline directions for future research on the use of edaphic specialists as model systems to study evolutionary processes across cellular, organismic, population, and community levels.

\section{How do Edaphic Endemics Evolve?}

Colonization of new environments, including edaphic islands, can be achieved by ecotypic differentiation via local adaptation or by phenotypic plasticity (Hereford, 2009; Palacio-López et al., 2015). Early studies in Sweden (Turesson, 1922) and California (Clausen et al., 1940) demonstrated that local adaptation is common in species distributed across altitudinal and climatic gradients. Similarly, elegant transplant experiments conducted by the British Ecological Society from the 1920s to the 1930s highlighted edaphic factors as potent agents of selection (Marsden-Jones \& Turrill, 1938). The long-term Park Grass Experiment in Rothamsted, UK (Silvertown et al., 2006), in which the grass Anthoxanthum odoratum was subjected to different fertilizer and lime treatments across multiple plots, showed local adaptation to soil types over a relatively short period. These studies exemplified how experimental methods such as common garden and reciprocal transplant experimentation can be used to examine how phenotypic plasticity and local adaptation contribute to habitat specialization (Wright \& Stanton, 2011).

Species living in harsh environments, including on edaphic islands, have genotypes either broadly tolerant to wide-ranging environmental conditions (Bradshaw, 2006) or locally adapted to specific ecological factors characteristic of the 'home' environment, i.e., ecotypes (Lowry, 2012). Ecotypes are a critical stage in the speciation process, and the recognition of such populations is vital for evolutionary studies (Via, 2009). The existence of sharp habitat boundaries between ecotypes is a compelling phenomenon that has provided some of the best experimental evidence of natural selection in the wild (Rajakaruna \& Whitton, 2004). Although there is much support for ecotypic differentiation and species-level endemism among flowering plants found on edaphic islands (O'Dell \& Rajakaruna, 2011), such edaphic specialization is not as welldocumented among ferns, gymnosperms, mycorrhizal fungi, lichens, or bryophytes (Rajakaruna et al., 2014).

It is important to examine factors and mechanisms driving rapid evolution in response to environmental pressures, such as those influencing plants on edaphic islands. Still, it is equally critical to pay attention to 'genostasis,' in which the lack of sufficient genetic variation may result in evolutionary failure (Bradshaw, 1991). Early work on mine tailings (Antonovics, 2006 and references therein) provides an example: at edges of mine tailings, some species maintain heavy metal-tolerant and -intolerant genotypes located only a few centimeters apart. In many other adjacent species, such edaphic differentiation is not found. Most species found off of mine tailings are unable to colonize metal-contaminated soil because they do not have the necessary alleles for adaptive variation (Antonovics, 1976). Additionally, a meta-analysis of studies of local 
adaptation showed that only $45 \%$ of population pairs (out of 1,032 compared) had better performance of the 'home' population relative to the 'away' population at both sites (Leimu \& Fischer, 2008). This suggests that habitat-mediated selection may not be as common in plants as generally assumed. Lack of local adaptation may result from reasons other than the lack of necessary genetic variance (Bell, 2012; Cheplick, 2015), including insufficient time for adaptive evolution, a high degree of phenotypic plasticity, extensive gene flow, and random genetic drift due to founder events. Further, lack of local adaptation may be a statistical/methodological artifact of choosing study habitats that are too similar in their major selection pressures (Cheplick, 2015).

Landmark papers on factors and mechanisms driving habitat specialization (Mason, 1946a, b; Raven, 1964) provided an early framework for understanding the role played by soil-based selection in the origin of new species. These ideas offered a context to envision a set of stages that may lead to the establishment of an edaphically endemic species, from the initial tolerance of an edaphic condition by preadapted genotypes to clear-cut species formation (Kruckeberg, 1986). While this sequence represents a relatively precise picture of the evolutionary pathways to endemism, it does not indicate why some genotypes evolve through all the steps and others do not. It is possible that there is a relatively higher cost of broad tolerance in edaphic endemic species relative to the cost of tolerance found in widespread taxa with broad edaphic tolerance (Kazakou et al., 2008; Maestri et al., 2010). Thus, only lineages experiencing a high cost of broad tolerance will be subjected to strong divergent selection across an edaphic boundary, leading to evolution of ecotypes and edaphic endemic species. The decisive step distinguishing an ecotype from an endemic species is likely the acquisition of complete reproductive isolation between the ancestral population and the ecotype, allowing an independent gene pool to evolve (Macnair \& Gardner, 1998; Lowry, 2012). How this occurs, especially when populations are not geographically isolated, is a fundamental question in speciation research (Kay et al., 2011; O'Dell \& Rajakaruna, 2011).

Populations that become geographically isolated can gradually acquire genetic differences through selection and drift, and eventually become reproductively isolated through the process of allopatric speciation. Past climate fluctuations and other dramatic environmental changes may have led to the extinction of widespread populations due to massive vegetation shifts such as those that occurred during postglacial reforestation (Slovák et al., 2012). Those surviving relict populations, especially those isolated on edaphic islands, may have become differentiated by means of allopatric speciation. Further, chance dispersal into novel edaphic habitats, particularly during strong climatic oscillations of the Quaternary, would have also provided conditions of relaxed competition, facilitating the evolution of edaphic specialization (Dillenberger \& Kadereit, 2013). Thus, allopatric speciation may be a particularly important pathway for the origin of edaphically restricted paleoendemic species (Table 1). Abrupt and sharply delineated edaphic habitats often provide opportunities for the divergence of edaphic specialist species along contact zones through the process of parapatric speciation (Table 1). There are major challenges, however, in demonstrating a parapatric origin for a species, as speciation must occur without a geographic barrier to gene flow. First, it is possible that 
Table 1 Proposed modes of speciation and substrate type for some taxa having presumably diversified under edaphic selection

\begin{tabular}{|c|c|c|c|}
\hline Species & Mode of Speciation & Type of Substrate & Reference \\
\hline Adiantum viridimontanum & Hybrid, Polyploid & Serpentine & $\begin{array}{l}\text { Paris \& Windham, 1988; } \\
\quad \text { Paris, } 1991\end{array}$ \\
\hline Arabidopsis spp. & Hybrid & Serpentine & Arnold et al., 2016 \\
\hline Arctostaphylos spp. & Hybrid & Serpentine & Gottlieb, 1968 \\
\hline Armeria spp. & Hybrid & Serpentine & Feliner et al., 1996 \\
\hline $\begin{array}{l}\text { Caulanthus amplexicaulis } \\
\text { var. barbarae }\end{array}$ & Allopatric & Serpentine & Pepper \& Norwood, 2001 \\
\hline Galium spp. & Hybrid & Serpentine & $\begin{array}{l}\text { Krahulcová \& Štěpánková, } \\
1998\end{array}$ \\
\hline Geonoma macrostachys & Sympatric & $\begin{array}{l}\text { Terra firme and moist } \\
\quad \text { flood plain }\end{array}$ & Borchsenius et al., 2016 \\
\hline Harmonia spp. & Allopatric & Serpentine & Baldwin, 1999 \\
\hline Helianthus spp. & $\begin{array}{l}\text { Hybrid, Polyploid, } \\
\text { Peripatric }\end{array}$ & $\begin{array}{l}\text { Desert, Sand Dune, } \\
\text { Salt Marshes }\end{array}$ & $\begin{array}{l}\text { Lai et al., 2005; Yakimowski } \\
\text { \& Rieseberg, } 2014 \text { and } \\
\text { references therein }\end{array}$ \\
\hline Hesperolinon spp. & Peripatric & Serpentine & Schneider et al., 2016 \\
\hline Howea spp. & Sympatric & Volcanic and carbonate & Savolainen et al., 2006 \\
\hline Iris spp. & Hybrid & Flooded soils & Martin et al., 2006 \\
\hline Knautia arvensis & Allopatric & Serpentine & Kaplan, 1998 \\
\hline Knautia spp. & Hybrid/Polyploid & Serpentine & Kolář et al., 2014 \\
\hline $\begin{array}{l}\text { Lasthenia californica } \\
\text { complex }\end{array}$ & Allopatric & $\begin{array}{l}\text { Ionically-harsh soils } \\
\text { such as saline, } \\
\text { serpentine, etc. }\end{array}$ & $\begin{array}{l}\text { Rajakaruna, 2003; } \\
\text { Kay et al., } 2011\end{array}$ \\
\hline Layia discodea & $\begin{array}{l}\text { Parapatric, } \\
\text { Peripatric }\end{array}$ & Serpentine & Baldwin, 2005 \\
\hline Leptosiphon parviflorus & Parapatric & Serpentine & Kay et al., 2011 \\
\hline Mentzelia monoensis & Peripatric & Silica-rich rhyolite tephra & Brokaw et al., 2015 \\
\hline Metal-tolerant grasses & Peripatric & Metal mines & Antonovics, 2006 \\
\hline Mimulus spp. & Peripatric & $\begin{array}{l}\text { Saline, Serpentine, } \\
\text { Dry/Wet }\end{array}$ & $\begin{array}{l}\text { Grossenbacher et al., 2014; } \\
\text { Selby et al., 2014; Sobel, } \\
2014\end{array}$ \\
\hline $\begin{array}{l}\text { Minuartia laricifolia } \\
\text { subsp. ophiolitica }\end{array}$ & Allopatric & Serpentine & Moore et al., 2013 \\
\hline Potentilla spp. & Hybrid & Serpentine & Paule et al., 2015 \\
\hline Protium spp. & Parapatric & White-Sand & $\begin{array}{c}\text { Fine et al., } 2013 \text { and } \\
\text { references therein }\end{array}$ \\
\hline Quercus spp. & Hybrid & Serpentine & Forde \& Faris, 1962 \\
\hline Silene dioica & Allopatric & Serpentine & Westerbergh \& Saura, 1992 \\
\hline $\begin{array}{l}\text { Streptanthus glandulosus } \\
\quad \text { complex }\end{array}$ & Allopatric & Serpentine & Mayer \& Soltis, 1994, 1999 \\
\hline
\end{tabular}


the initial evolution of traits driving reproductive isolation may have occurred under allopatric conditions (Pettengill \& Moeller, 2012); a new species that evolved under allopatry may subsequently come into contact along an edaphic boundary and appear identical to parapatric species in being relatively young, ecologically divergent, and reproductively isolated. Further, reinforcement of reproductive isolation (Pfennig \& Pfennig, 2009), a process by which selection can minimize maladaptive hybridization, may take place upon contact with those populations that initially diverged under allopatry, thereby completing the speciation process. Genetic analyses can help distinguish whether divergence first occurred in allopatry and speciation was completed by reinforcement (Widmer et al., 2009), although extensive introgression and hybridization following secondary contact may make such determinations difficult (Barraclough \& Vogler, 2000; Ortiz-Barrientos et al., 2009; Strasburg et al., 2012). How speciation can proceed in the face of gene flow between potentially interbreeding populations, including among parents and newly formed hybrid species (Andrew et al., 2012; Renaut et al., 2013), is especially revealing of the challenges associated with habitat specialization under parapatry. Gene flow can dilute the adaptive differences that selection generates between divergent populations; this may be especially problematic when one population is significantly larger than the other, as in the case of a newly divergent population found adjacent to an ancestral population, or in the presence of asymmetric gene flow (Ellstrand, 2014). However, if the edaphic condition confers strong selection pressures on one side of the edaphic barrier and there is strong selection against the tolerance genes on the other side of the edaphic boundary (i.e., low 'Haldanian' fitness), then one could expect evolution to occur even in the presence of gene flow.

Similarly, case studies of sympatric speciation (i.e., evolution from a single ancestral species in the same location) must demonstrate species co-existence, sister relationships, reproductive isolation, and that a former allopatric phase is highly unlikely. In two palm species of Howea, endemic to the remote Lord Howe Island, Australia, divergence in blooming periods is strongly correlated with soil type; only a few genetic loci are more divergent between the two species than expected under neutrality, a finding consistent with sympatric speciation involving disruptive or divergent selection (Savolainen et al., 2006; Fig. 1a). Morphotypes of the palm Geonoma macrostachys in Peruvian lowland forests provide another example of sympatric speciation likely occurring between ecologically divergent (via soil and light) and reproductively isolated (via phenology and pollinators) populations (Borchsenius et al., 2016).

Budding or peripatric speciation is a diversification process through which new species form at the periphery of an ancestral population. In this case, a few preadapted genotypes encounter and colonize an edaphic island resulting in edaphic specialization. Budding speciation appears to be especially common in plants (Crawford, 2010), as high rates of selfing (Antonovics, 1968) and polyploidization (Soltis et al., 2004) result in abrupt reproductive isolation between the ancestral and derivative populations. As the initial peripheral populations are small, they can often quickly acquire reproductive isolation via catastrophic selection, i.e., differential survival during an episode of mass extinction (Gottlieb, 2004), or strong divergent selection (Grossenbacher et al., 2014). At the time of speciation, sister taxa will exhibit highly asymmetrical and completely or partially overlapping distributions, yet occupy distinct microhabitats (Gottlieb, 2004), such as edaphically contrasting microsites. Eighty percent of the sister species of Mimulus show patterns consistent with budding speciation: pairs are broadly sympatric, 


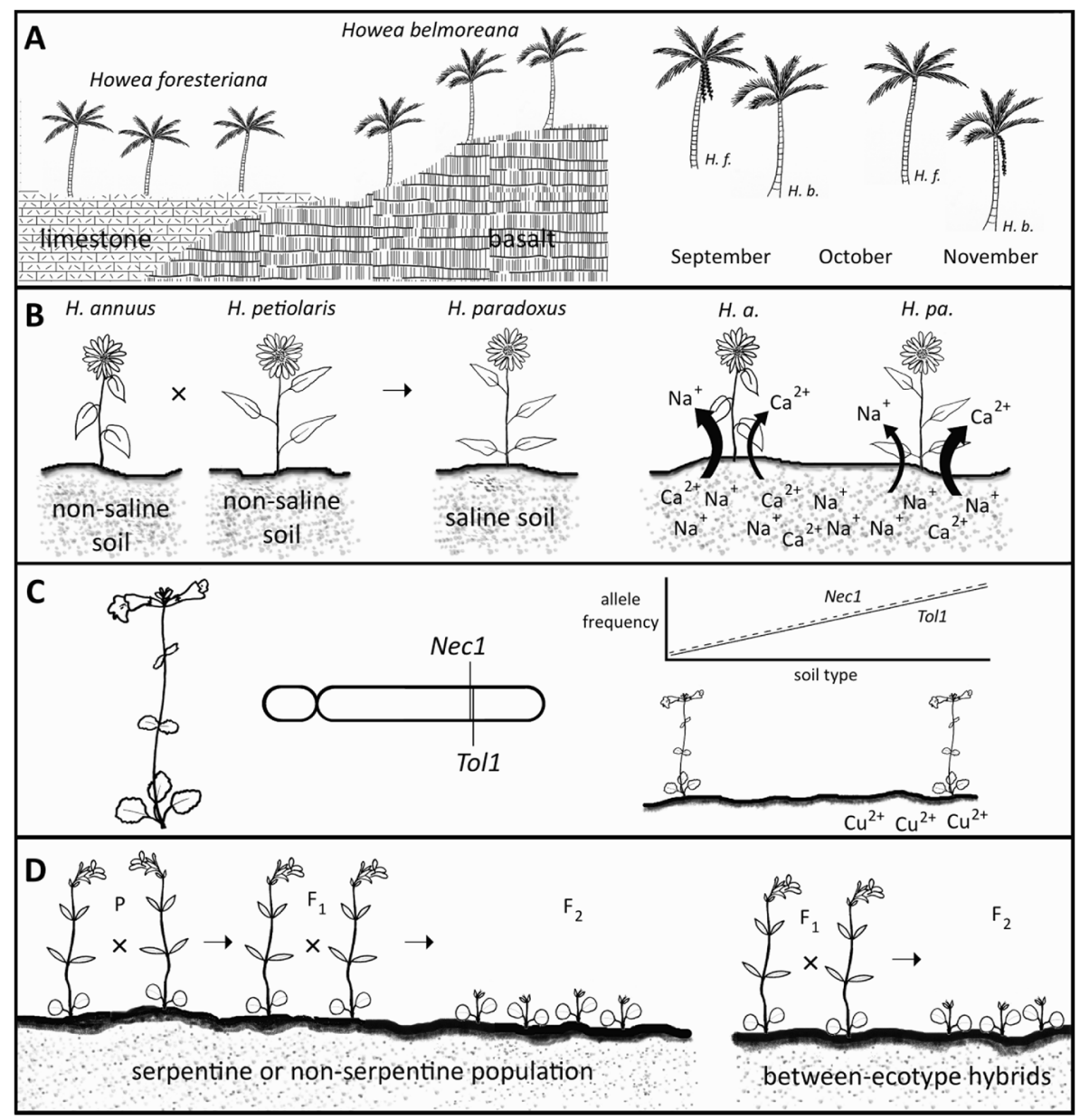

Fig. 1 Examples of edaphic influence on speciation and reproductive isolation. A Howea foresteriana is largely restricted to limestone, while H. belmoreana is largely restricted to basalt (Savolainen et al., 2006; Hipperson et al., 2016). Their geographic separation is accompanied by reproductive isolation via a difference in flowering time: peak flowering in $H$. foresteriana $(H . f$.) occurs around two months before H. belmoreana $(H$. b.). B Helianthus annuus $(H$. a.) and $H$. petiolaris are salt-intolerant species (glycophytes), but H. paradoxus (H. pa.), which originated as a hybrid between the former two species, is a halophyte (Lexer et al., 2003; 2004). Genetic studies suggest that this may be due to changes in the expression of genes for ion transporters, with increased calcium uptake limiting sodium uptake in the halophyte (Edelist et al., 2009). C Mimulus guttatus has both copper-tolerant and -intolerant populations in California. The alleles for copper tolerance (Toll) and hybrid lethality $(\mathrm{Necl})$ are at closely linked genetic loci; as selection for copper tolerance occurred, both alleles rose to high frequency in the population on copper-contaminated soil (Wright et al., 2013). D Collinsia sparsiflora has serpentine and nonserpentine ecotypes. Progeny of within-ecotype crosses have high fertility; between-ecotype hybrids do occur, but the genetic distance between the ecotypes is maintained because these hybrids have reduced fertility (ca. 26\% reduction in seed viability in F1; Moyle et al., 2012). Image Credit: Ian D. Medeiros

have highly asymmetric distributions, and occupy distinct habitats (Grossenbacher et al., 2014), suggesting that ecologically divergent taxa in this genus (Lowry et al., 2008) may have arisen from budding or peripatric speciation (see Table 1 for additional case studies). 
A meta-analysis of phylogenies available for plants in the California Floristic Province (CFP) showed that of 71 sister pairs from 12 families, 57 pairs $(80 \%)$ were broadly sympatric (Anacker \& Strauss, 2014). Range sizes of sisters differed by a mean of 10-fold and range overlap and range asymmetry were greatest in younger sisters, suggesting that in the CFP, budding speciation has been an important pathway for the origin of neoendemic species. Interestingly, of the 71 sister pairs they examined, 29 (41\%) showed complete edaphic shifts whereas 20 (28\%) showed partial edaphic shifts, strongly implying that budding speciation via edaphic specialization is commonplace in the edaphically-heterogeneous landscape of the CFP. Similarly, in the Cape Floristic Region (CFR) of South Africa, 87\% of sister species show partial or complete ecological shifts; however, complete edaphic shifts were found in only $17 \%$ of CFR pairs (van der Niet \& Johnson, 2009) versus in $41 \%$ of the CFP pairs. This difference may be attributable to lower levels of edaphic and topographic heterogeneity in the CFR compared to the CFP, likely making edaphic transitions less significant in speciation (Anacker \& Strauss, 2014).

Hybridization, with or without polyploidy, can play a critical role in the origin and establishment of edaphic specialists (Abbott et al., 2013; De Storme \& Mason, 2014), especially under parapatric, sympatric, and peripatric modes of speciation. Studies of the relative importance of hybridization and polyploidization on the origin of edaphic endemics show that introgression between close relatives and subsequent adaptation of hybrid offspring to novel edaphic conditions, when directly or indirectly resulting in reproductive isolation with parental taxa, can result in the origin and establishment of hybrid species (Table 1). Edaphic divergence of the hybrid species from its parental taxa appears to be central to the successful origin of several hybrid species, occurring even in the absence of post-zygotic isolation caused by chromosomal and other genetic incompatibilities (Abbott et al., 2010). There is strong evidence, via reciprocal transplant and common garden approaches, for greater fitness of a hybrid in a novel edaphic habitat relative to that of parental taxa for the sand dune specialist Helianthus anomalus and the salt marsh specialist H. paradoxus (Fig. 1b), although such conclusive evidence is lacking for another hybrid species, H. deserticola (Edelist et al., 2009; Donovan et al., 2010). Similarly, a Salix hybrid complex from the European Alps has greater tolerance to cold temperatures and nutrient-poor/low $\mathrm{pH}$ soils than either parent (Gramlich et al., 2016). The hybrids appear to have originated after glaciers retreated and established persistent populations within a few decades. A major factor contributing to hybrid establishment under sympatric settings is the ability to occupy more extreme edaphic niches relative to either parent species (Abbott et al., 2010; Gramlich et al., 2016).

\section{Are Edaphic Endemics New or Old Species?}

Edaphic specialists, formed through the multiple modes described above, have often been used to compare the relative importance of rapid versus gradual speciation in the origin of endemic species (Pepper \& Norwood, 2001; Anacker, 2014). Edaphic specialists can arise under both of these scenarios (i.e., rapid versus gradual). Recently evolved neoendemics can evolve from nearby, non-specialized relatives via rapid and local speciation, including via parapatric, sympatric, and peripatric modes (Anacker \& 


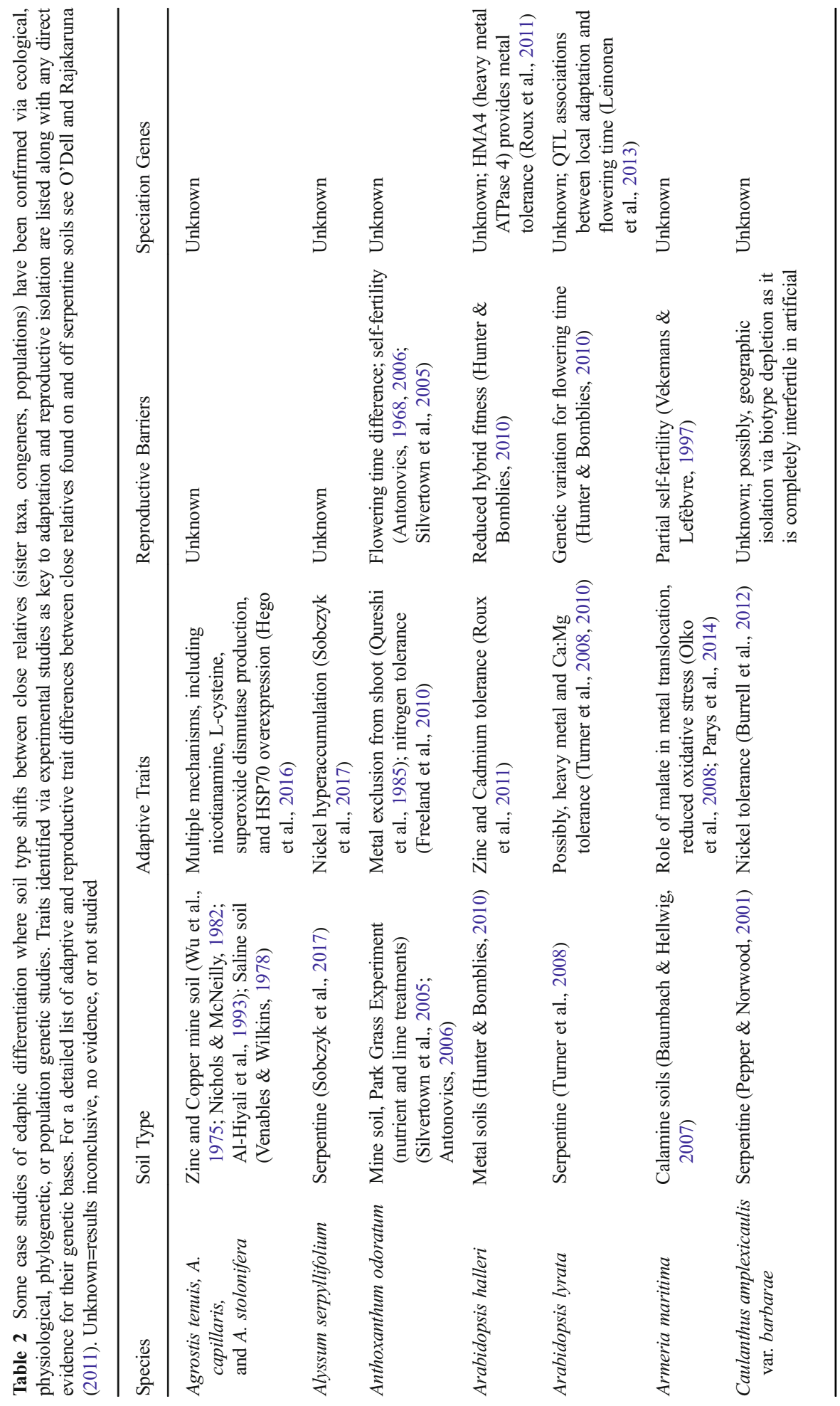




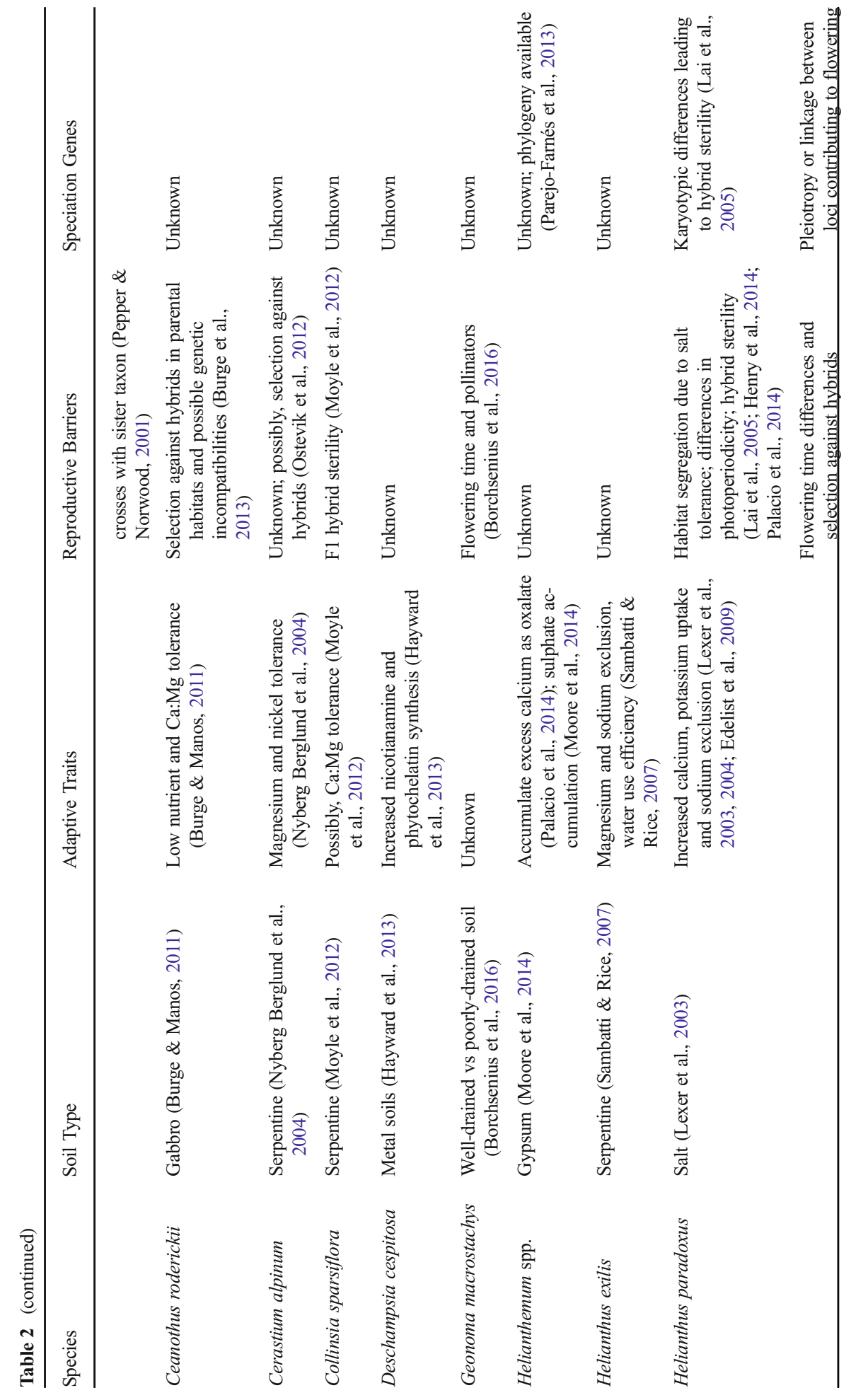




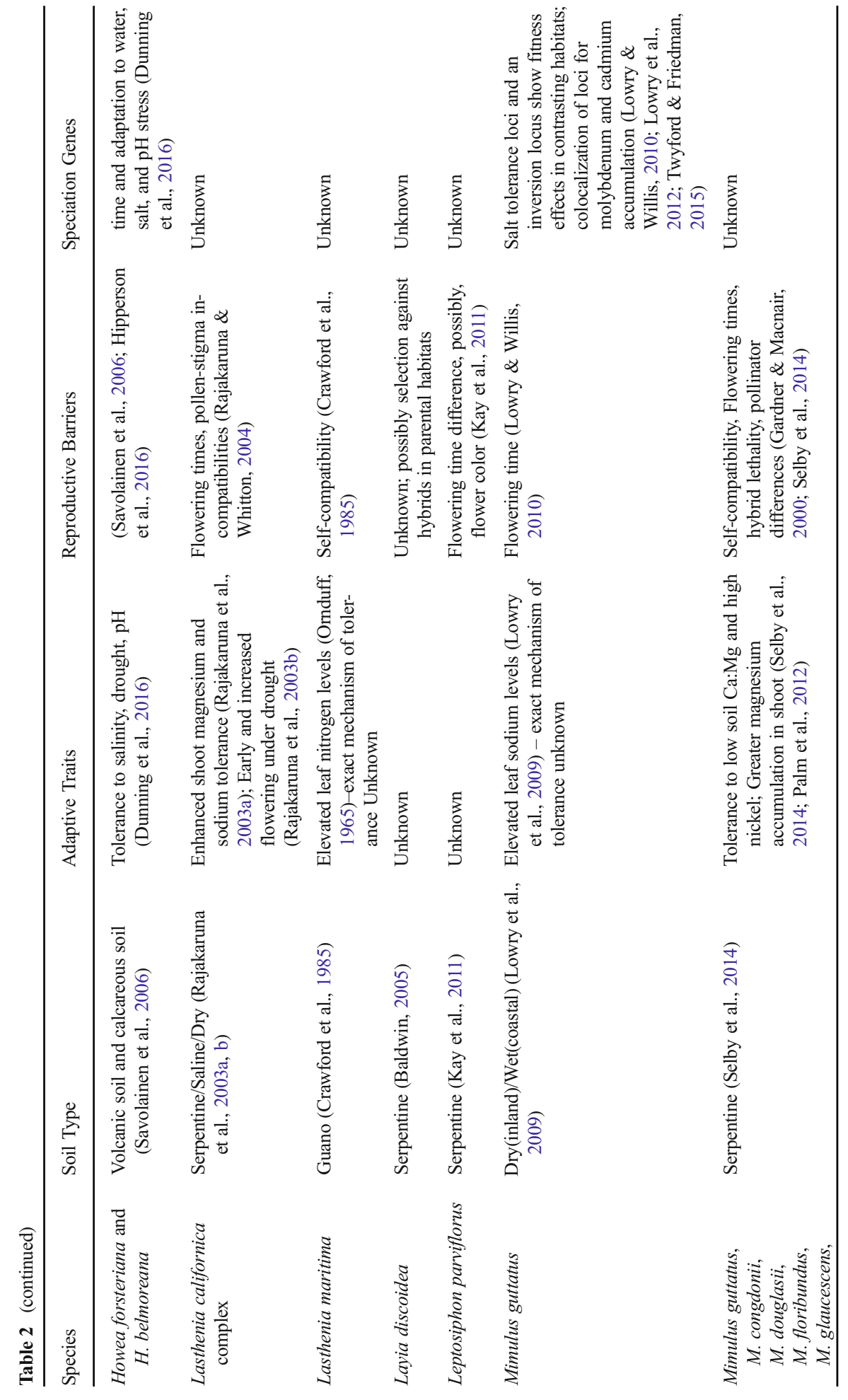




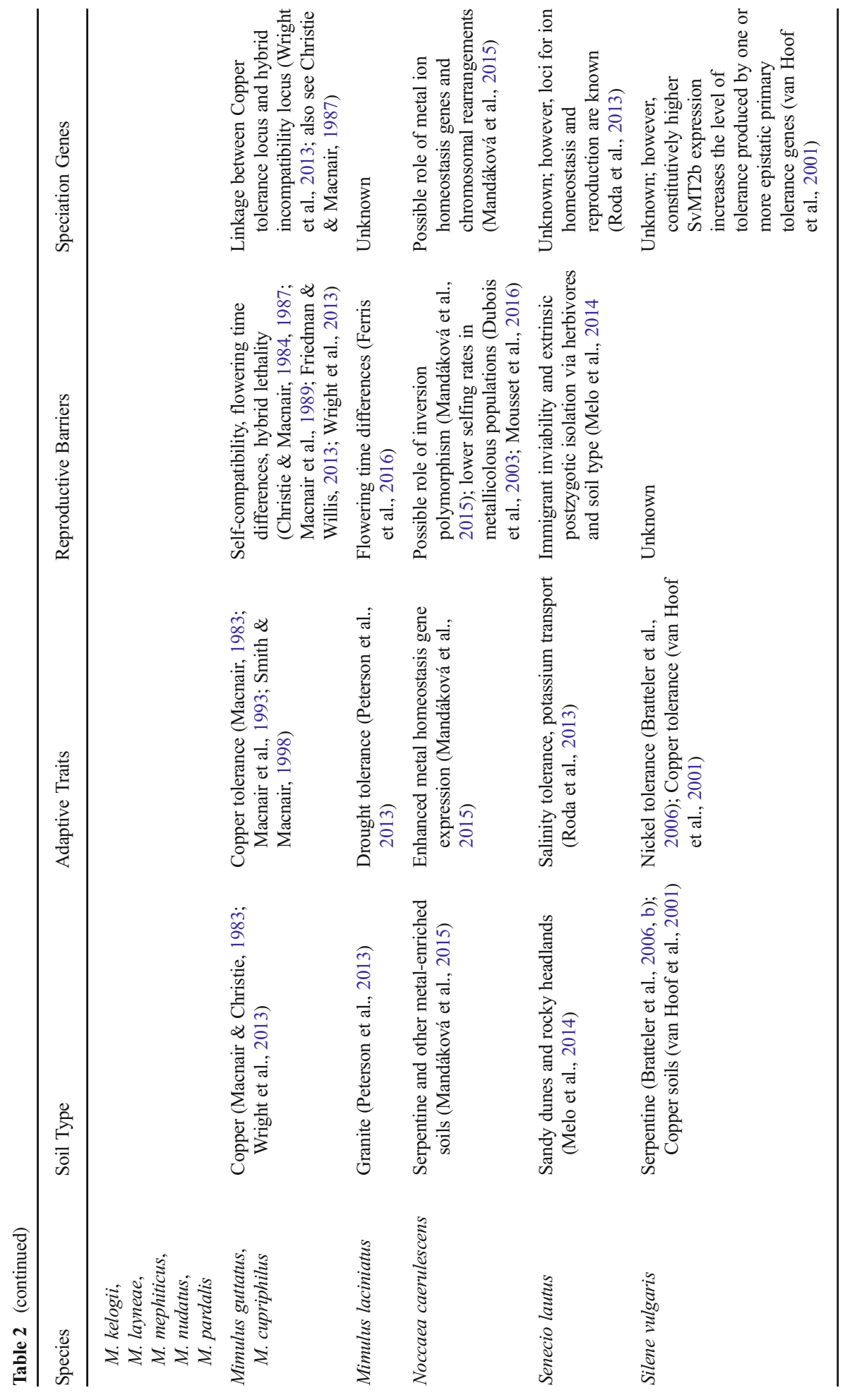


Strauss, 2014; Ferris et al., 2014; Schneider et al., 2016). In contrast, ancient paleoendemics may have evolved via gradual speciation through biotype depletion, including via allopatric (vicariant) speciation, as has been shown for the Streptanthus glandulosus complex (Mayer \& Soltis, 1994), Caulanthus amplexicaulis var. barbarae (Pepper \& Norwood, 2001), and for Minuartia spp. (Moore et al., 2013; Moore \& Kadereit, 2013; Table 1). There is ample evidence from studies of edaphic specialists that large-scale geographic isolation is not always critical for diversification; total reproductive isolation can be achieved even in the face of gene flow (Antonovics, 2006). In fact, recent phylogenetic investigations suggest that neoendemism may be the norm in cases of edaphic specialization, not the exception (Baldwin, 2014). Peripatric or budding speciation is an especially common mode of speciation among neoendemic edaphic specialists, with high rates of selfing and polyploidization causing immediate reproductive isolation between adjacent yet edaphically distinct populations (Gottlieb, 2004). Strong directional and disruptive selection that often occurs across edaphic boundaries, combined with parallel changes contributing to reproductive isolation between divergent populations, can lead to rapid and local speciation (Levin, 1993; Crawford, 2010). In peripatric speciation, the progenitor species is initially paraphyletic; however, lineage sorting and extinction will eventually result in monophyly (Crawford, 2010). Case studies of edaphic differentiation in which there are phylogenetic or population genetic data to support relatedness between edaphically divergent taxa are listed in Table 2 along with additional evidence for edaphic divergence via ecological, physiological, reproductive, or genetic studies (when available).

\section{How Does Adaptation Contribute to Reproductive Isolation?}

Establishing a direct or indirect link between traits that confer edaphic adaptation and traits that contribute to reproductive isolation is strong evidence for the role of edaphic factors in the divergence of species (Hopkins, 2013; Wright et al., 2013). Classic studies of plants on mine tailings in Europe (Antonovics, 2006 and references therein) clearly demonstrated that rapid and repeated evolution of metal tolerance is often associated with the evolution of prezygotic isolating mechanisms, including the evolution of both self-compatibility (Mousset et al., 2016 and references therein) and earlier flowering in metal-tolerant populations (Antonovics, 2006 and references therein). Both of these traits significantly limit gene flow between divergent populations, aiding in the evolution of independent gene pools under strong edaphic selection. Flowering time shifts in Anthoxanthum odoratum in the Park Grass Experiment, at the boundaries between plots vastly varying in soil $\mathrm{pH}$, have resulted in reduced gene flow (Silvertown et al., 2005). Adjacent populations that had a common origin at the start of the experiment in 1856 have now diverged at neutral marker loci, suggesting that reinforcement (i.e., selection against maladaptive hybridization) has been key to completing speciation. Establishing a direct link between $\mathrm{pH}$ tolerance and flowering time is necessary to confirm the role of such reinforcement in speciation. Interestingly, there was no indication of reinforcement at the boundaries of plots with smaller $\mathrm{pH}$ differentials, suggesting a link between $\mathrm{pH}$ preference and flowering time. Earlier flowering times have often been documented for serpentine-associated taxa, including those in the Lasthenia californica complex (Yost et al., 2012), Helianthus exilis (Sambatti \& Rice, 
2007), Mimulus spp. (Macnair \& Gardner, 1998; Selby et al., 2014), Gilia capitata (Kruckeberg, 1951), and Leptosiphon spp. (Kay et al., 2011). Near complete reproductive isolation between coastal and inland populations of Mimulus guttatus has been achieved by selection against immigrants and flowering time differences (Lowry et al., 2008). The annual, inland populations exposed to more summer drought flower early compared to the perennial populations along the coast on more moist soils. Diversification within the stone plant genus Argyroderma of the Western Cape Province in South Africa also appears to have occurred through allopatric adaptive speciation, under strong edaphic-mediated divergent selection along with reproductive isolation achieved through divergence in flowering times (Ellis et al., 2006). In the well documented case of sympatric speciation in Howea, the shift in flowering phenology between species on volcanic and calcareous soils dramatically reduced interspecific gene flow (Hipperson et al., 2016; Fig. 1a). There also appears to be a pleiotropy between flowering time and adaptation to drought, salinity, and $\mathrm{pH}$, driving speciation (Dunning et al., 2016). Temporal isolation is a key factor in facilitating plant speciation; however, flowering time differences between close relatives can arise as a flexible response to divergent edaphic conditions (Levin, 2009) or through direct or pleiotropic genetic effects of edaphic adaptations (Hunter \& Bomblies, 2010; Selby et al., 2014).

Soil constituents, such as heavy metals, are directly implicated in causing reproductive isolation between close relatives. Copper tolerance in Mimulus guttatus is expressed in the sporophyte as well as in the pistil (Searcy \& MacNair, 1993). Copper in the pistils acts as a selective agent since seed production is reduced when pollen donors are maladapted to copper-rich soils (Searcy \& Mulcahy, 1985; Searcy \& MacNair, 1990). Metal accumulation in reproductive organs generates a strong prezygotic isolating mechanism by decreasing reproductive output in crosses between edaphically divergent parents. Therefore, edaphic factors directly act as reproductive barriers, favoring reproduction between plants growing under similar edaphic conditions and minimizing gene flow between edaphically divergent taxa.

Serpentine tolerant Brassicaceae endemics can limit nickel uptake into the shoot, particularly into reproductive organs, while non-endemics accumulate significantly more nickel into reproductive organs relative to shoots (Meindl et al., 2014). In the selenium hyperaccumulating Stanleya pinnata, selenium is preferentially allocated to flowers, while the non-accumulating relative Brassica juncea has higher selenium concentrations in leaves relative to flowers (Quinn et al., 2011a). Selenium had no effect on pollen germination in the hyperaccumulator, but it impaired pollen germination in the relative, showing a possible evolutionary cost for selenium accumulation through decreased pollen germination in the non-accumulating taxon.

Pollinators can distinguish between 'clean' nectar and that contaminated with metals, and avoid nectar enriched with metal because of toxicity (Meindl \& Ashman, 2013). Pollinator preference of nectar, therefore, can potentially limit gene flow between close relatives found on distinct substrates. Additional trait differences between edaphically divergent taxa can also act as reproductive barriers, including flower size differences leading to differential pollinator preferences (Gardner \& Macnair, 2000) and pollen-stigma incompatibilities leading to reduced potential for fertilization (Rajakaruna \& Whitton, 2004).

Edaphic specialists also provide opportunities for examining how post-zygotic isolating mechanisms contribute to edaphic divergence. In the Mimulus guttatus 
complex, there is evidence for inviability in hybrids between metal-tolerant and intolerant parents (Gardner \& MacNair, 2000), although such post-zygotic isolation is not a factor between coastal and inland ecotypes of the same taxon (Lowry et al., 2008). Work on copper tolerance in M. guttatus (Macnair \& Christie, 1983; Wright et al., 2013) has revealed a genetic association between edaphic tolerance and hybrid inviability (Fig. 1c). In Collinsia sparsiflora, ecotypic adaptation to serpentine is associated with the expression of hybrid sterility between serpentine and nonserpentine ecotypes, over spatial scales of less than $1 \mathrm{~km}$ (Wright \& Stanton, 2007; Moyle et al., 2012; Fig. 1d). Further, allozyme (Wright \& Stanton, 2011) and microsatellite data (Moyle et al., 2012) suggest there is little genetic differentiation between ecotypes, indicating that hybrid sterility may have recently evolved.

A potentially fascinating example of the relationship between adaptation and reproductive isolation yet to be studied lies in the progenitor-derivative species pair of Layia glandulosa subsp. lutea and L. discoidea (Baldwin, 2005). Unlike Mimulus, in which hybrid lethality has been documented between copper-tolerant and -intolerant taxa (Wright et al., 2013), there is complete fertility between artificial crosses of the serpentine-intolerant and serpentine-endemic Layia species; however, spontaneous hybrids are not found in nature, suggesting that partially or completely reduced hybrid fitness in one or both parental habitats may be responsible for the diversification. Additionally, it is unknown whether the flower shape (discoid- vs. ray-flowered) plays a role in pollinator preferences or whether potential differences in flowering time, especially when populations occur along contact zones, contribute to pre-zygotic isolation. Similarly, factors contributing to reproductive isolation between the guanoendemic Lasthenia maritima and its close relative, the coastal bluff-specialist L. minor, are little-known (Rajakaruna, 2004). There is evidence for greater self-compatibility within the guano-endemic (Crawford et al., 1985), resembling the trends shown for some metal-tolerant species (Mousset et al., 2016 and references therein); however, it is unclear whether other isolation barriers, such as differences in pollinators or flowering times, or hybrid lethality and reduced fitness of hybrids in parental habitats, also contribute to preserving isolation. Further, the physiological bases for guano adaptation are also unknown. Whether the high nutrient content (nitrogen, phosphorus), low $\mathrm{pH}$ (due to uric and other acids), or some other chemical or physical factor of guano drives selection on these substrates needs further investigation. For both Layia and Lasthenia case studies, QTL-based comparative genome mapping and transcript profiling approaches (Sun \& Schliekelman, 2011) can be used to determine whether any traits conferring adaptation to substrate have effects on traits contributing to reproductive isolation between the divergent taxa.

\section{Are Edaphic Endemics Evolutionary Dead-Ends?}

The growing availability of molecular phylogenies has provided us with means to investigate the evolutionary dynamics of habitat specialization (Vamosi et al., 2014), including directionality of evolution of edaphic endemism (Anacker et al., 2011). Population genetic and phylogenetic analyses of serpentine-tolerant plants (Mengoni et al., 2003a, b; Nyberg Berglund et al., 2004; Anacker, 2011), metallophytes (Mengoni et al., 2001; Pauwels et al., 2005), halophytes (Bennett et al., 2013), calciphiles (Klein 
\& Kadereit, 2015), and gypsophiles (Bresowar \& McGlaughlin, 2015) have demonstrated that tolerance to edaphic conditions has been gained numerous times within various groups of angiosperms and has even been lost in some groups, suggesting that traits conferring edaphic tolerance are evolutionarily labile. Further, differences in the evolutionary dynamics (i.e., gains vs. losses) of edaphic tolerance documented among different lineages may result from association of edaphic tolerance traits with other ecophysiological traits related to tolerance of environmental stresses, with edaphic tolerance being more easily gained in preadapted lineages (Saslis-Lagoudakis et al., 2014; Selby et al., 2014). The direction of serpentine endemism among genera with serpentine-tolerant species in California is mostly from non-tolerant and -tolerant species to endemic species, with a few reversals from the tolerant or endemic state to the non-tolerant state (Anacker et al., 2011). This suggests that the evolution of edaphic endemism may represent an evolutionary dead-end. This may not always be the case, however, as endemics are often able to influence adjacent populations by repeated episodes of introgression and polyploidization. In the diploid-tetraploid complex of Knautia arvensis, recurrent polyploidization within serpentine populations followed by hybridization with the neighboring non-serpentine tetraploid populations, has allowed serpentine tetraploids to escape from their serpentine refuge and spread further into non-serpentine habitats (Koláŕ et al., 2012). Similarly, endemic Streptanthus clades are often quite diverse, with endemism having evolved numerous times and having been lost at least once (Cacho et al., 2014). In Arabidopsis, there is also evidence for serpentine-tolerant loci being introgressed from one serpentine-endemic to another (Arnold et al., 2016) and for hybridization between two sympatric and diploid limestone endemics, giving rise to a tetraploid siliceous soil endemic (Schmickl \& Koch, 2011). These findings suggest that edaphic endemism does not always represent an evolutionary dead-end and that endemics have the potential to further diversify within (Cacho et al., 2014) or across substrates (Schmickl \& Koch, 2011).

\section{How Does Tolerance to Edaphic Extremes Influence Competitiveness in 'Normal' Soils?}

Edaphic islands have long been considered a refuge from competition (Kruckeberg, 1954), suggesting that tolerance to edaphic extremes has a cost. However, the idea of a trade-off of competitive ability for tolerance (i.e., trade-off hypothesis) needs close scrutiny via experimentation (Harper et al., 1997a). Edaphic specialists, compared to non-specialists, often appear to be less competitive (Milla et al., 2011; Moore et al., 2013; Anacker, 2014; Bastida et al., 2014) and more susceptible to herbivory when found on 'normal' soils (Dechamps et al., 2008; Kay et al., 2011; Strauss \& Boyd, 2011). However, plants that specialize in a particular edaphic setting (e.g., a metal mine) may have adapted not only to the increased metal concentrations but also to other stressors such as drought, low nutrients, high light, and poor soil structure characterizing the mine site. Therefore, it is unclear if a reduction in fitness or competitive ability results from the direct cost associated with metal tolerance per se (i.e., trade-off hypothesis) or with other correlated traits conferring adaptation to the mine site. To demonstrate that a negative correlation between traits is the result of pleiotropy (and not via gene/s in linkage disequilibrium with metal tolerance gene/s) it is essential to 
experimentally demonstrate that the traits are genetically correlated (Partridge \& Sibly, 1991). Experimental studies on copper tolerance in Mimulus guttatus (Harper et al., 1997a), however, provide no clear evidence in support of a trade-off hypothesis. Additionally, low fitness of metal tolerant plants in 'normal' environments can also result from an increased metabolic requirement for the metal (i.e., metal requirement hypothesis). Studies conducted on M. guttatus, however, show no such increased requirement for copper (Harper et al., 1997b, 1998), suggesting that neither the tradeoff hypothesis nor the metal requirement hypothesis can fully explain the cost of copper tolerance in M. guttatus. Additional experimentation will likely reveal that it is not one trait but a suite of adaptive traits (i.e., genes, their modifiers, and the interactions between them; see Smith \& Macnair, 1998) that has a cost in a 'normal' habitat. Similarly, there is little evidence of a cost for tolerance to either low soil calcium to magnesium ratios or high concentrations of heavy metals, two key selective pressures experienced by plants growing on serpentine soils (Brady et al., 2005; Kay et al., 2011). Serpentine endemics, however, are typically slow-growing and stress-tolerant, rather than fast-growing and what is typically considered as competitively superior (Anacker \& Harrison, 2012; Fernandez-Going et al., 2012), consistent with the notion of a tradeoff between competitive ability and tolerance to serpentine. Indigenous resistant plants on serpentine soil have less competition from invasive species when growing on serpentine soil (Harrison, 1999; Gram et al., 2004; Going et al., 2009), but are poor competitors on high-nutrient soils (Rice, 1989; Jurjavcic et al., 2002; Vallano et al., 2012). Regardless, the evidence that competition is reduced on serpentine soils (Moore \& Elmendorf, 2011) and that edaphic endemics are competitively inferior is not substantial (Powell \& Knight, 2009; Fernandez-Going \& Harrison, 2013). Furthermore, these hypotheses of a cost of tolerance have not been tested in numerous lineages, nor have they been examined across distinct substrate types.

Comparing pairs of sister taxa could help reveal the evolutionary costs of habitat specialization relative to broad tolerance and address why some species become edaphic specialists whereas others maintain general-purpose genotypes (sensu Baker, 1965) that can tolerate wide-ranging habitat conditions. A widely-distributed Aquilegia subspecies has greater adaptive phenotypic plasticity and higher competitive ability than a related taxon that is a narrow endemic (Bastida et al., 2014). This suggests that adaptive plasticity, competitive ability, and lineage history all contribute to phenotypic divergence, edaphic niche specialization, and range distribution.

The hypothesis of a greater cost of tolerance and resulting trade-offs in competitive ability is, however, gaining recognition as a potentially important driving force in the evolution of edaphic endemism. The integration of molecular phylogenies with descriptive and experimental ecological data reveals that occupation of bare habitats is a precursor for serpentine specialization in Streptanthus and close allies (Cacho \& Strauss, 2014) and may be central to soil specialization. When comparing ancestorderivative species pairs, it was evident that shifts onto serpentine soils were not from soils with a low calcium to magnesium ratio or high nickel content (like those characteristic of serpentine soils) but from bare microhabitats. Preadaptations to features characterizing bare habitats, including water stress, combined with inherently lower competitive ability, perhaps due to increased investment for defense (Strauss \& Cacho, 2013), may have enabled the colonization of serpentine (also, see von Wettberg et al., 2014), leading to multiple origins of serpentine adaptation among Streptanthus 
and allies (Armbruster, 2014). Whether such preadaptation to bare habitats is a precursor for adaptation to other rock outcrop plant communities can be tested via similar approaches, using a combination of molecular phylogenetic and ecological data (Cacho \& Strauss, 2014).

\section{Does Parallel Evolution Occur Frequently in Edaphic Specialists?}

Parallel (or repeated) evolution provides strong evidence for the role of ecology in driving divergence (Nosil, 2012). Parallel edaphic adaptation may be achieved via the evolution of novel alleles contributing to specialization or via parallel increases in the frequency of alleles (Faria et al., 2014). Repeated evolution of traits may not be unusual in clades that have undergone ecological radiation, particularly in those taxa adapted to environments imposing strong divergent selection such as harsh edaphic environments (Levin, 2001; Mengoni et al., 2003a, b). When changes in edaphic tolerance are associated with changes in reproductive compatibility, a case for parallel ecological speciation can be made (Rajakaruna \& Whitton, 2004). Contrary to these findings, there are only a limited number of studies showing the repeated evolution of traits conferring adaptation and reproductive isolation in plants, i.e., parallel ecological speciation (Ostevik et al., 2012). Interestingly, of the 23 potential cases for parallel ecological speciation cited by Ostevik et al. (2012), 10 are from plants adapted to harsh edaphic conditions (see Table 1 in Ostevik et al., 2012). The prevalence of cases of edaphic adaptation among the limited number of studies of parallel ecological speciation suggests that parallel evolution appears to occur more often in, or is better known from, edaphic specialists relative to other species. Genomic methods can play an important role in determining whether parallel (via independent evolution of the same or different genes; Nichols \& McNeilly, 1982; Levin, 2001; Rajakaruna et al., 2003c) or horizontal gene flow of clustered genes (via introgression; Arnold et al., 2016) are responsible for the parallel evolution of edaphic tolerance.

\section{Do Interactions with Herbivores or Microbes Drive the Evolution of Edaphic Specialization?}

Plant interactions with other organisms, including those that are mutualistic and antagonistic, appear to have a role in edaphic specialization (Strauss \& Boyd, 2011; Van Nuland, 2016). Harsh soils, which are often nutrient-poor, water-stressed, traceelement rich, and found in barren and open landscapes, may increase physiological costs associated with herbivore damage as well as make plants more conspicuous to herbivores (Strauss \& Boyd, 2011). Edaphic specialists may be more susceptible to herbivory than their non-specialist relatives and plant-herbivore interactions can sometimes be central to edaphic specialization (Fine et al., 2004; Van Zandt, 2007; Lau et al., 2008). Increased herbivore pressure due to increased noticeability on rock outcrops can drive increased investment in defense strategies among edaphic specialists (Strauss \& Cacho, 2013). The high costs of defense can result in trade-offs in plant competitiveness (Fine et al., 2006) and restrict plant distributions on harsh soils, contributing to high rates of edaphic endemism. Similarly, the pathogen refuge hypothesis 
(Kruckeberg, 1992; Springer, 2007) suggests that plants will experience lower disease pressure on serpentine and other edaphically harsh environments, either through reduced disease transmission rates in sparsely populated serpentine plant communities (Thrall et al., 2007) or through lowered disease-associated damage, as has been shown for serpentine-adapted Hesperolinon (Springer, 2009). Serpentine specialists within Hesperolinon are less susceptible to fungal infection, perhaps due to their ability to selectively uptake calcium, which is required to initiate an effective immune response. Less specialized species appear to be more susceptible to fungal disease on serpentine soil (Springer, 2007, 2009). Such a pathogen-refuge effect might also reinforce edaphic associations among plants and promote greater edaphic specialization. In parapatric coastal populations of Senecio lautus, herbivores have a central role in preventing gene flow in the field via differential seedling predation of both migrants and hybrids, whereas soil elemental content contributes to divergent selection on populations both locally and on a geographic scale (Melo et al., 2014).

Specialization in plant host-symbiont-soil interactions may also facilitate plant adaptation to edaphic stress and subsequent specialization (see Table 2 in Van Nuland, 2016). Arbuscular mycorrhizal fungi (AMF) are common root symbionts that can increase a plant hosts' establishment and growth in edaphically-stressful environments (Palacio et al., 2012; Schechter \& Branco, 2014; Southworth et al., 2014). There are plant and microbial symbionts that enhance plant adaptation to edaphic stress (Thrall et al., 2007), showing that co-adapted interactions may play a role in edaphic specialization. For example, arsenic-tolerant AMF suppress high-affinity arsenate/ phosphate transport in the roots and decreases arsenic uptake by the arsenic-tolerant grass, Holcus lanatus, showing that arsenic-tolerant AMF may contribute to enhanced arsenic-tolerance in the metal-tolerant populations of the grass (Gonzalez-Chavez et al., 2002). However, salt-tolerant Acacia species from a high-salinity environment are less dependent on Rhizobium bacteria than salt-sensitive hosts from less stressful environments, suggesting plant-rhizobial mutualisms may be less important in plant adaptation to salinity (Thrall et al., 2008). Arbuscular mycorrhizal fungal assemblages associated with serpentine and non-serpentine ecotypes of Collinsia sparsiflora showed that plant ecotypes are associated with distinct AMF assemblages (Schechter \& Bruns, 2008); however, a common garden test of host-symbiont specificity provided no evidence of adapted host ecotype-AMF specificity, suggesting that soil type, not microbial specificity, is key to determining AMF assemblage structure in C. sparsiflora (Schechter \& Bruns, 2013). Findings on plant host-microbial symbiont specificity and the role of AMF on edaphic stress tolerance in higher plants are variable (Thrall et al., 2008; Glassmand \& Casper, 2012); some AMF, however, have the capacity to confer metal tolerance in some plant host species either via sequestration or by contributing to growth enhancement via increased nutrient acquisition (Schechter \& Branco, 2014). Such mutualistic interactions are clearly beneficial for some plant species, allowing them to colonize harsh soils and thus setting the stage for potential divergence.

The ecological and evolutionary significance of metal hyperaccumulation has received much attention (Boyd, 2014). The selective pressure for resistance to pathogens and herbivores may also result in fixation of metal hyperaccumulating trait(s) in plant populations (Boyd, 2007; Hörger et al., 2013). Metal (and metalloid) hyperaccumulation has a profound effect on cross-kingdom interactions (El Mehdawi \& Pilon-Smits, 2012; Boyd, 2014) as metal-hyperaccumulating plants offer a 
specialized niche for metal-tolerant herbivores, pollinators, microbes, and neighboring plants. For example, high levels of metal in plant tissues reduce herbivory (Quinn et al., 2010) and pathogen infection (Fones et al., 2010) and result in increased litter decomposition by specialized microbes (Quinn et al., 2011b), causing an elemental allelopathic effect on metal-intolerant neighbors (El Mehdawi et al., 2011); all these effects can influence the fitness of plants accumulating the metal, thereby contributing to edaphic specialization. Plant-microbe interactions may also influence gene flow between divergent populations due to microbe-assisted edaphic differentiation. A study of an Artemisia hybrid zone in central Utah showed that the microbial community influenced the performance of parental and hybrid plants in native and nonnative soils, segregating the distinct populations and likely contributing to their edaphic divergence (Miglia, 2007).

Metal-hyperaccumulator plants found on serpentine and other metal-rich environments are hosts to insects that appear to have co-evolved with them (Boyd, 2014). Some of these insects do accumulate heavy metals to toxic levels (Boyd, 2007) and may use them as defense against natural enemies (i.e. elemental defense hypothesis; Boyd, 2007). Although only one study supports this hypothesis (Boyd \& Wall, 2001), little research regarding this hypothesis has been conducted to date. There is also no overwhelming evidence for a cost of hyperaccumulation in terms of reproductive functions or pollinator visitation. For example, pollinators of Stanleya pinnata, a Sehyperaccumulator, showed no visitation preference between high- and low-Se plants, suggesting greater tolerance to the metalloid (Quinn et al., 2011a). Whether the presence of aluminum and nickel in nectar of Impatiens capensis alters foraging behavior by bumblebees has also been investigated (Meindl \& Ashman, 2013). The presence of aluminum in nectar did not influence foraging patterns; however, flowers containing nickel-laden nectar solutions had shorter visits relative to controls, and even resulted in reduced visitation of nearby nickel-contaminated flowers. Reduced visitation by native pollinators has also been documented for Streptanthus polygaloides (Meindl \& Ashman, 2014) which accumulates nickel in pollinator rewards such as nectar and anthers. Although heavy metal effects on plant-pollinator interactions are clearly context-dependent, edaphic features, such as heavy metal concentrations, have the capacity to influence gene flow and reproductive isolation between close relatives through pollinator selection.

\section{Are Edaphic Specialists More or Less Sensitive to Climate Change?}

Species can respond to climate-associated stressors via both phenotypic plasticity and local adaptation (Valladares et al., 2014). Edaphic specialists, many of which display largely disjunct but widespread distributions, are ideal models for exploring how climate interacts with edaphic factors to influence plant distribution (Damschen et al., 2010; Sánchez et al., 2017). It is easy to envision how an altered climate regime can have differential effects on populations of an ecologically widespread taxon. For example, serpentine populations are generally better-adapted to low moisture conditions typical of their mostly exposed, rocky, and shallow soils (Wu et al., 2010) and may be able to withstand increased aridity and high temperatures. Therefore, under a drying climate, as is predicted for some parts of the world, nonserpentine populations 
may be extirpated, whereas serpentine populations, already preadapted to aridity, could survive and become endemic due to the extinction of the more widespread nonserpentine populations (Moore et al., 2013; but see Anacker, 2014). Pronounced climatic oscillations of the Quaternary period appear to have forced populations of Sempervivum, Jovibarba, and Adenostyles to respond via latitudinal or altitudinal shifts into edaphically unsuitable but relatively competition-free habitats (Klein \& Kadereit, 2015). This set the stage for the divergence of edaphically specialized species via allopatric speciation. A similar scenario is presented for the evolution of the edaphically specialized Lilium pyrophilum (Douglas et al., 2011).

There is increasing evidence that climatic and edaphic factors interact to control local adaptation and substrate endemism (Fernandez-Going, 2014). Serpentine endemism peaks in wet regions both in California and some other parts of the world (Anacker, 2011; Fernandez-Going, 2014), likely due to increased competition on 'normal' substrates under more productive climates. At the community level, there is also more species, functional, and phylogenetic turnover across edaphic boundaries in mesic relative to arid regions of California (Anacker \& Harrison, 2012). Furthermore, serpentine endemics in California generally occupy wetter regions than even their closest relatives (Fernandez-Going, 2014), but this is only true in the case of neoendemics arising from serpentine-intolerant ancestors; more productive climates may have been more suitable for the persistence of small neoendemic taxa with novel adaptations during and after speciation. Paleoendemics, on the other hand, occupy similar climates to those of their closest relatives, suggesting that range contractions leading to biotype depletion may have been similar in arid and mesic regions (Anacker, 2014). It is as of yet unclear whether climate can alter soil-specific competitiveness in edaphic endemics (see Fernandez-Going \& Harrison, 2013) and whether paleoendemics and neoendemics differ in their sensitivities to competition.

Climate change will clearly have differential effects on the ranges of edaphic specialists. In California, future climate conditions may extend the potential range of many endemics (Loarie et al., 2008); however, whether edaphic endemics can naturally disperse to suitable habitat is questionable (Damschen et al., 2012; Spasojevic et al., 2014). Preadaptations to dry conditions may allow edaphic specialists to expand their current range (Fernandez-Going et al., 2012; Fernandez-Going, 2014) and even be more competitive with non-specialists off of their special edaphic niche (Moore et al., 2013). Tolerance of edaphic stress appears to go hand-in-hand with tolerance of climatic stress for plants growing on serpentine soils, linking soil infertility to a stress-tolerant functional trait syndrome that confers unusually high resistance to climate change upon plant species and communities (Harrison et al., 2015). Therefore, in the absence of nutrient deposition, stress-tolerant invasive species, and habitat loss, edaphic specialists may perform better under future warmer/drier climates relative to plants adapted to more fertile soils. With possible range expansions onto 'new' habitat, however, they will no longer be restricted to their special edaphic niche, thereby losing their edaphic endemic status (Anacker, 2014). Habitat patchiness may also contribute to invasiveness, with competitive and dispersal abilities evolving more rapidly on island-like habitats (Williams et al., 2016), suggesting that fragmentation can select for more rapid invasion velocity. How these findings are influenced by different climatic regimes, or by habitat patches with different levels of edaphic stress, are also important avenues for research. Naturally fragmented edaphic islands, such as 
serpentine outcrops, are model habitats for exploring such questions and for testing the roles of patch size, shape, type (soil), and isolation in ecological and evolutionary processes (Gil-López et al., 2014).

\section{What is the Genetic Basis of Edaphic Specialization and Speciation?}

In the era of genomics, there are many tools (e.g., Bratteler et al., 2006a, b; von Wettberg \& Wright, 2011; Selby et al., 2014) at our disposal to explore the genetic basis of adaptation to harsh environments, including the nature of adaptation to dissimilar habitats with similar abiotic stressors (e.g., arid and saline habitats contributing to water stress, saline and serpentine soils contributing to ionic stress, or serpentine and carbonate soils contributing to high $\mathrm{pH}$ ). Phylogenetic analyses show that there is a significant association between halophytes and metal hyperaccumulators, although within each group there is low phylogenetic clustering (Moray et al., 2016), suggesting that salinity and metal tolerance can vary among close relatives. In Asteraceae, Amaranthaceae, Fabaceae, and Poaceae, halophytes and hyperaccumulators are more closely related than would be expected if the two traits had evolved independently, suggesting a strong genetic association between the abilities to tolerate salt and heavy metals. Studies of evolutionary ecology now routinely use high-throughput sequencing and other genomic approaches to examine the genetic basis of speciation (Tiffin \& Ross-Ibarra, 2014) and these methods have clearly promoted the study of edaphic adaptation (Turner et al., 2010; Porter et al., 2017).

Genomic polymorphisms that are differentiated between edaphically contrasting populations can reveal candidate loci for edaphic adaptation. Gene pool sequencing of serpentine and granitic populations of Arabidopsis lyrata from the USA shows that the polymorphisms that are most strongly associated with soil type are loci for heavy-metal detoxification and calcium and magnesium transport, providing several candidate loci for serpentine adaptation (Turner et al., 2010), including CAX7, which appears to be responsible for adaptation to low calcium to magnesium ratios characteristic of serpentine soils (Turner et al., 2008). Moreover, the same associations between individual loci and serpentine tolerance were observed in the European subspecies of $A$. lyrata, further implicating edaphic selection. The sequencing of three candidate loci in the European subspecies indicated parallel differentiation of the same polymorphism at one locus, confirming edaphic specialization, and different polymorphisms at two other loci, suggesting convergent evolution. Whether these loci also contribute to reproductive isolation between progenitor-derivative taxon pairs is unknown.

Adaptation to low soil calcium to magnesium ratios has often been suggested as key to serpentine tolerance (Palm \& Van Volkenburgh, 2014). In serpentine-intolerant Arabidopsis thaliana, an induced loss of function mutation in the $\mathrm{Ca}^{2+}-\mathrm{H}^{+}$antiporter, $C A X 1$, enhances survival on soils with a low calcium to magnesium ratio (Bradshaw, 2005). $C A X 1$ is a high-capacity $\mathrm{Ca}^{2+}-\mathrm{H}^{+}$antiporter that maintains cytoplasmic ion homeostasis by pumping excess calcium from the cytoplasm into the vacuole (Cheng et al., 2003). Mutation of CAX1 effectively acts as a magnesium exclusion strategy, enabling the plant to maintain adequate cytoplasmic calcium concentrations under the low calcium to magnesium ratios encountered on serpentine soils. 
Additional candidate genes have recently been identified for serpentine adaptation in autotetraploid Arabidopsis arenosa, providing evidence that some selected alleles were introgressed from the diploid serpentine-endemic A. lyrata, whereas others were independently involved in separate adaptation events in the two species (Arnold et al., 2016). The research by Arnold et al. (2016) shows strong evidence for selection on genes that control specific ion homeostasis-related traits, as well as drought adaptation. Although several alleles under selection appear to have been introgressed from A. lyrata, others have been independently selected following serpentine colonization in both species. The significant overlap between selected genes in serpentine-endemic A. arenosa and A. lyrata suggests that adaptations to serpentine are not qualitatively different between diploid and tetraploid species. The work described above on Arabidopsis (Turner et al., 2008, 2010; Arnold et al., 2016) advances our understanding of the polygenic basis of multi-trait adaptation to serpentine soils and its repeatability across species. Further, the work suggests that edaphic divergence can occur even in the presence of high levels of inter- and intraspecific gene flow. Serpentine-tolerant Arabidopsis taxa, along with their close relatives, can provide a useful system for investigating the genetics of speciation under the serpentine influence.

The genetic tools at our disposal (Sun \& Schliekelman, 2011; von Wettberg \& Wright, 2011; Tiffin \& Ross-Ibarra, 2014) can reveal the genetic architecture of adaptive traits that confer reproductive isolation (i.e., speciation genes; Nosil \& Schluter, 2011) and whether the same alleles or different alleles contribute to parallel evolution (Ostevik et al., 2012), revealing new insights into the mechanisms by which natural selection can bring about adaptation, reproductive isolation, and speciation. Mechanisms resulting in reproductive isolation may be incidental byproducts of natural selection on linked loci or on loci with pleiotropic effects. For example, plant populations on serpentine and other harsh edaphic settings often flower early (O'Dell \& Rajakaruna, 2011). Such phenological isolation could be a byproduct of adaptation to harsh soils or a result of an independent set of genetic changes that were favored by natural selection (Baack et al., 2015). A detailed genetic analysis of the alleles responsible for reproductive barriers can separate these hypotheses, particularly when traits are correlated and contribute to reproductive isolation. In Mimulus, differences in flowering time are often associated with differences in soil water availability (Wu et al., 2010; Friedman \& Willis, 2013). In wet coastal and dry inland populations of Mimulus guttatus (Lowry et al., 2008), an inversion polymorphism appears to be a major quantitative trait locus (QTL) for flowering time and growth-related traits, explaining $20-30 \%$ of the variation observed between populations (Lowry \& Willis, 2010). Reciprocal transplant experiments have demonstrated strong local adaptation in traits that map to the inversion and differ between the coastal and inland ecotypes (Lowry et al., 2008; Hall et al., 2010).

In Mimulus guttatus, the locus that contributes to copper tolerance also leads to hybrid lethality in crosses between copper-tolerant and -intolerant populations (Macnair \& Christie, 1983). High-resolution genome mapping show that copper tolerance and hybrid lethality are not caused by the same gene, but are separately controlled by two tightly linked loci (Wright et al., 2013; Fig. 1c). Selection on the copper tolerance locus indirectly causes the hybrid incompatibility allele to increase in frequency in the mine population via hitchhiking. Therefore, hybrid incompatibilities can evolve as a byproduct of an adaptation to a novel edaphic environment. Whether there are similar 
bases for hybrid lethality between edaphically divergent ecotypes of serpentine tolerant species such as Collinsia sparsiflora (Moyle et al., 2012; Fig. 1d) remains to be seen.

Current model systems are not representative of all life history strategies and are mostly restricted to herbs, and we need to continue to add new model systems to allow comparative approaches for exploring the intricacies of adaptive evolution (Selby et al., 2014; von Wettberg et al., 2014). In this regard, the extensive work on the genetics of metal tolerance (Verbruggen et al., 2009) in metal-accumulating and hyperaccumulating plants used in phytoremediation (Rascio \& Navari-Izzo, 2011), and work on the genetics of abiotic stress tolerance and phenology in crops (Roy et al., 2011), are important for examining the genetic bases for edaphic adaptation and species divergence.

\section{Conclusions and Future Directions}

Edaphic specialists are key players in the study of local adaptation and ecological speciation (Crawford et al., 2014). Ecological, physiological, phylogenetic, and population genomic studies of plants growing on serpentine, saline, and metal-contaminated soils continue to shed light on factors and mechanisms driving ecological speciation (Table 2). Studies such as those on Mimulus on copper-enriched soil (Macnair \& Christie, 1983; Macnair et al., 1993; Wright et al., 2013; Fig. 1c], Collinsia and Arabidopsis on serpentine soil (Moyle et al., 2012; Turner et al., 2010; Fig. 1d), Helianthus on saline soils (Edelist et al., 2009; Fig. 1b], and Senecio on sand dunes and rocky headland soils (Melo et al., 2014), are key to establishing a direct link between adaptation, reproductive isolation, and subsequent speciation. Ongoing research on Mimulus, Helianthus, and Arabidopsis (and others; Tables 1 and 2) will continue to unravel how edaphic conditions can directly or indirectly contribute to species divergence.

\section{Lessons on Evolution}

There are several key lessons on evolutionary processes from the study of edaphic specialization:

a. Both adaptive phenotypic plasticity and local adaptation contribute to edaphic divergence. Edaphic specialization is key to diversification in some groups; however, in others, there appears to be lack of variation for adaptation to harsh soils. Although edaphic specialization is important in the diversification of flowering plants and ferns, there is little evidence for its significance in other plant groups such as gymnosperms and bryophytes or in lichens, soil algae, and cyanoprokaryotes.

b. Although edaphic specialists can evolve under allopatric, parapatric, and sympatric modes of speciation, there is strong evidence pointing to budding or peripatric speciation being central to the origin of neoendemic species (Anacker \& Strauss, 2014). Additionally, an increasing body of work shows that speciation is possible in the face of gene flow, especially in lineages where there is considerable ecological (including edaphic) divergence. Further, introgression between close relatives can also lead to the acquisition of edaphic tolerance (Arnold et al., 2016). 
c. Edaphic adaptations have direct or indirect effects on reproductive isolation; adaptive and reproductively isolating traits can evolve rapidly and repeatedly in some lineages, making edaphic specialists key to studying parallel speciation.

d. There is mixed evidence for a physiological cost of edaphic tolerance driving habitat specialization, although both reduced competitive ability and greater susceptibility to herbivory have been documented among some edaphic specialists when grown in 'normal' soils.

e. Mutualistic and antagonistic interactions with other organisms can mediate edaphic specialization either by directly enhancing tolerance to edaphic extremes via the action of microbes or by reducing gene flow between divergent populations via the action of pollinators, herbivores, and pathogens.

f. Climate and soils can interact to influence edaphic specialization. Future climates may further restrict the distribution of edaphic specialists due to increased competition from invasive species. However, edaphic specialists could also expand their ranges, even outside their edaphic niche, if their preadaptations to drought make them more competitive than non-specialists under a drying climate.

g. QTL mapping studies, population genomic approaches, and high-throughput phenotyping assays, when combined with reciprocal transplant studies using hybrid mapping populations (including, F2, backcross, near isogenic lines, and recombinant inbred lines), can identify major loci contributing to edaphic adaptation to serpentine, saline, and heavy metal-rich soils (Selby et al., 2014). These loci often have direct or indirect effects on loci that contribute to reproductive isolation (Table 2).

\section{Information Gaps and Future Directions}

There are several information gaps that need to be addressed to better develop current model systems as well as to incorporate additional taxa for the study of edaphic specialization. The following are key areas for future research:

a. The identification of specific soil factors that are central to edaphic specialization is important for demonstrating the role of adaptation in speciation. Although most studies state only the general soil type (e.g., serpentine versus non-serpentine, saline versus non-saline, gypsum versus non-gypsum, etc.) being investigated, a handful of studies have attempted to examine the exact soil chemical or physical factor contributing to the specialization and/or divergence (Rajakaruna et al., 2003a, b; Bradshaw, 2005; Bratteler et al., 2006, b; Palacio et al., 2007; Edelist et al., 2009; Selby et al., 2014). Identifying the key soil variable or variables is more effective when comparing sister populations found across substrates that differ in a distinct way (e.g., with or without a heavy metal as in the case of copper tolerance in Mimulus). Plant ionomic approaches can also be used to investigate ecological functions of ionomic alleles in the adaptation to distinct soils (Lowry et al., 2012; Huang \& Salt, 2016).

b. Better characterization of functional traits (e.g., morphological, physiological, and reproductive traits) between sister species that differ in their edaphic niche is also critical for determining which traits may be contributing to the divergence. Whether 
traits characteristic of the edaphic habitat are plastic responses or are genetically based should also be confirmed. Once those traits targeted by edaphic selection are identified, the physiological/genetic basis of those traits should be determined. Much of what we know about edaphic specialization comes from studies on plants found on metal mines, serpentine soils, or saline environments of temperate or Mediterranean climes, and it is essential that we expand our studies to identify and characterize systems found on other types of substrates and in other climatic regions of the world. Such a broad survey can reveal similarities and differences in trends associated with speciation resulting from edaphic specialization.

c. Because multiple reproductive barriers can contribute to reduced gene flow between divergent taxa (Baack et al., 2015; Ostevik et al., 2016), it is important to identify and characterize the relative contribution of all pre- and post-zygotic reproductive isolating mechanisms to the total reproductive isolation between edaphically divergent pairs. The order in which barriers originate and their genetic bases and associations with traits characterizing edaphic adaptations may shed light on the relative importance of each barrier to different stages of a divergence event and at different levels of habitat specialization.

d. Why edaphic tolerance only sometimes leads to speciation is still unknown. It is possible that speciation is more likely when an adaptation or a suite of adaptations comes with a large fitness trade-off between edaphic habitats, contributing to stronger divergent selection across edaphic boundaries. A greater cost of tolerance may lead to adaptations that have a direct or indirect effect on reproductive isolation, leading to the evolution of endemic species. This fundamental gap in our understanding of edaphic specialization can be answered by using multiple, progenitor-derivative taxon pairs that have adaptively diverged along the same edaphic axis but which vary in their accommodation to the substrate (i.e., tolerator versus endemic). Field surveys to characterize the habitat differences (i.e., are endemics found on harsher soils than tolerator species?), reciprocal transplant studies to estimate the fitness trade-offs (i.e., is there a greater cost of tolerance in species pairs with endemics relative to those with tolerators?), and greenhouse studies to assess the extent of reproductive isolation between pairs (i.e., is there greater reproductive isolation in species pairs with endemics relative to those with tolerators) can reveal answers to this critical question.

e. Edaphic specialists offer opportunities, via methods of comparative genomic and population genetic analyses, to examine the relationships among genetic loci that are responsible for adaptations and the degree to which they influence reproductive isolation (Crawford et al., 2014). In addition to the elegant work done on model plants such as Helianthus (Andrew \& Rieseberg, 2013), Mimulus (Selby et al., 2014), and Arabidopsis (Turner et al., 2008, 2010; Arnold et al., 2016), the genetic architecture of traits conferring adaptation and reproductive isolation should be explored in other species with good ecological and biological data supporting edaphic differentiation. Serpentine-tolerant plants such as Silene (Bratteler et al., 2006, b), Lasthenia (Rajakaruna, 2003), Layia (Baldwin, 2005), Leptosiphon (Kay et al., 2011), Streptanthus (Pope et al., 2014), and Collinsia (Moyle et al., 2012); metal-tolerant plants including Alyssum, Caulanthus, and Thalspi (Noccaea) (Mengoni et al., 2003a, b; Burrell et al., 2012; Gill et al., 2012); selenium-tolerant plants such as Stanleya and Astragalus (Schiavon \& 
Pilon-Smits, 2017); and gypsophiles such as Mentzelia, Nama, and Helianthemum (Moore et al., 2014 and references therein) are ideal for testing how findings from the model plants may be applicable across a wider range of wild plants experiencing a broader array of edaphic pressures. Taxa within these genera show a range of divergence stages and degrees of edaphic endemism and, in many cases, their natural history and ecology are well documented via both descriptive and experimental methods. For some of these taxa (or their close relatives), there are extensive genetic tools already in place. Genome scans, when combined with candidate gene approaches, comparative transcriptomics, QTL mapping, functional analysis, and experimental manipulation, can reveal loci with high levels of differentiation between edaphically divergent populations, enabling the discovery of genes driving adaptation and reproductive isolation (Selby et al., 2014; Faria et al., 2014; Hoban et al., 2016). In species for which there is evidence for parallel evolution of traits, it will be critical to test whether the same or different alleles are responsible for the parallel speciation events (Ostevik et al., 2012; Roda et al., 2013).

f. Edaphic specialists can help determine how prezygotic and postzygotic reproductive isolating mechanisms limit gene flow between close relatives at various geographical scales. The often widely disjunct and patchy distribution patterns of edaphic specialists provide settings in which to test whether pre-zygotic isolating mechanisms are stronger in populations in parapatry/sympatry relative to those in allopatry. Enhanced reproductive isolation between edaphically divergent taxa found under parapatry/sympatry, relative to those in allopatry, may reflect the action of reinforcement, i.e., selection for reduced gene flow to avoid maladaptive hybridization (Widmer et al., 2009). There are only a few welldocumented cases of reinforcement in plants (Baack et al., 2015) and edaphic specialists may provide good model systems for testing the importance of this process in plant speciation (see Silvertown et al., 2005).

g. Comparative genomic and population genetic analyses can reveal how habitat specialization is achieved and maintained in the face of gene flow (Papadopulos et al., 2011). Hybridization and polyploidization are ubiquitous forces in the diversification of plants, and edaphic endemic species can help reveal how these two forces influence divergence (Kane, 2009).

h. Chromosomal rearrangements can contribute to reproductive isolation through their effects on hybrid fertility, as well as by reducing interspecific recombination and gene flow (Baack et al., 2015). In Mimulus, a chromosomal inversion polymorphism contributes to differences in flowering time and other traits, as well as multiple reproductive barriers between annual and perennial ecotypes of M. guttatus (Lowry \& Willis, 2010). Whether karyological anomalies drive isolation between edaphically divergent individuals must be tested on species pairs showing post-mating and post-zygotic isolation.

i. If soil elements, like heavy metals, have a direct impact on reproductive isolation of edaphically divergent taxa, it is easy to demonstrate that adaptation to a specific soil factor can directly contribute to isolation and subsequent divergence. The work exploring how heavy metal accumulation in reproductive tissue can influence reproductive success (Searcy \& MacNair, 1993; Quinn et al., 2011a), including pollinator-mediated isolation (Meindl \& Ashman, 2013, 2014, 2015), is 
important for further exploration, especially in sister taxa in which one taxon is a metal hyperaccumulator.

j. Metal hyperaccumulators have received much attention as candidates for green technologies such as phytoremediation and phytomining (Rascio \& Navari-Izzo, 2011). However, they also provide opportunities for exploring the cost of edaphic tolerance hypothesis on habitat specialization. In genera with metal-tolerant, metal-hyperaccumulating, and metal-intolerant species (such as in Alyssum, Thlaspi/Noccaea, Streptanthus, and Silene), sister taxa can be used to test whether there is a trade-off in terms of competitive ability between metal-intolerant versus metal-tolerant and metal-intolerant versus metal hyperaccumulator sisters (prediction: greater trade-off in the metal-intolerant versus metal-hyperaccumulator pair). Further, to explore if the cost of tolerance to edaphic specialization drives speciation, one could test whether there is a greater trade-off between metal-intolerant versus edaphic endemic metal hyperaccumulator pairs or metal-intolerant versus nonendemic metal hyperaccumulator pairs (prediction: greater trade-off in competitive ability in the metal intolerant versus edaphic endemic metal hyperaccumulator pair).

k. Plants found in stressful environments tend to share a suite of traits (i.e., stress resistance syndrome or SRS traits) that provides cross-tolerance to a range of low productivity habitats (Brady et al., 2005; von Wettberg et al., 2014 and references therein). It is unclear if the same SRS loci or different loci are responsible for edaphic shifts seen across distinct substrates (e.g., between serpentine and limestone, serpentine and saline, serpentine and mine tailing, limestone and dolomite/gypsum, etc.) characterized by overlapping selection pressures (e.g., drought, $\mathrm{pH}$, ionic strength, ions, etc.). If SRS traits are shared (with or without a similar genetic basis), one can envision how an adaptation to one 'harsh' soil type can preadapt a lineage to another 'harsh' soil type. In Mimulus, Arabidopsis, Helianthus, and others such as Lasthenia (Rajakaruna, 2003), Silene (Mengoni et al., 2001), and Minuartia (Moore \& Kadereit, 2013) there are multiple species showing adaptation to numerous soil types, including those characterized by similar selection pressures: ions, $\mathrm{pH}$, drought, etc. Ecological, phylogenomic, and population genomic studies of plants showing such cross-tolerance to distinct soil types can provide insights on common physiological traits and trends associated with edaphic specialization.

1. Climate change is clearly a major stressor influencing plant diversity. How edaphic specialists will respond to climate change may depend on whether they are preadapted to future climate conditions, cross-tolerant to edaphic-climatic stressors (e.g., salt-drought), can compete under novel climates, or can rapidly evolve climate tolerance, as well as how quickly, how far, and how effectively they can disperse into suitable edaphic niches under a changing climate (Fernandez-Going, 2014). Further, how cross kingdom interactions (both mutualistic and antagonistic) might play into these possible outcomes is unknown. Studies of the interaction between climate and edaphic factors in determining the distribution of edaphic specialists should incorporate species from multiple lineages, growth forms, substrate types, and varying climates to gain a better 
understanding of how climate-associated threats will impact edaphically specialized plants.

The study of edaphic specialization continues to provide unique perspectives on the processes of evolution and will continue to lead the way in understanding the important role ecology plays in the origin of species and assembly of special plant communities. The fast-growing field of molecular ecology will undoubtedly play a key role in this regard, especially by aiding in the discovery of genes responsible for adaptation and reproductive isolation under edaphic influences. Edaphically specialized plants will also provide model systems for exploring little-studied phenomena in plant evolution such as the importance of reinforcement of reproductive isolation in speciation and the nature of parallel speciation. Lastly, research on edaphic specialization, particularly the study of adaptation to edaphic factors such as nutrient levels, salt, heavy metals, and drought, will help counter growing challenges faced in fields such as agriculture (Rozema \& Schat, 2013) and habitat restoration (O’Dell, 2014), and contribute to advancing green technologies, including phytoremediation and phytomining (Chaney et al., 2014).

Acknowledgments I would like to thank Bob Boyd, Ian Medeiros, Elizabeth Farnsworth, Susan Harrison, Tanner Harris, and Jonathan Gressel for constructive comments on earlier drafts of the manuscript. Additional comments from Mark R. Macnair and an anonymous reviewer greatly improved the manuscript. Funding from the US-Sri Lanka Fulbright Commission during the writing of this review is gratefully acknowledged.

\section{Literature Cited}

Abbott, R. J., M. J. Hegarty, S. J. Hiscock \& A. C. Brennan. 2010. Homoploid hybrid speciation in action. Taxon 59: 1375-1386.

, D. Albach, S. Ansell, J. W. Arntzen, S. J. E. Baird, N. Bierne, J. Boughman, A. Brelsford, C. A. Buerkle, R. Buggs, R. K. Butlin, U. Dieckmann, F. Eroukhmanoff, A. Grill, S. H. Cahan, J. S. Hermansen, G. Hewitt, A. G. Hudson, C. Jiggins, J. Jones, B. Keller, T. Marczewski, J. Mallet, P. Martinez-Rodriguez, M. Möst, S. Mullen, R. Nichols, A. W. Nolte, C. Parisod, K. Pfennig, A. M. Rice, M. G. Ritchie, B. Seifert, C. M. Smadja, R. Stelkens, J. M. Szymura, R. Väinölä, J. B. W. Wolf \& D. Zinner. 2013. Hybridization and speciation. Journal of Evolutionary Biology 26: 229-246.

Al-Hiyali, S. A. K., T. McNeilly, A. D. Bradshaw \& A. M. Mortimer. 1993. The effect of zinc contamination from electricity pylons. Genetic constraints on selection for zinc tolerance. Heredity 70: 22-32.

Anacker, B. L. 2011. Phylogenetic patterns of endemism and diversity. Pp. 49-79. In: S.P. Harrison \& N. Rajakaruna (eds.), Serpentine: the evolution and ecology of a model system. University of California Press, Berkeley.

—, J. Whittall, E. Goldberg \& S. P. Harrison. 2011. Origins and consequences of serpentine endemism in the California flora. Evolution 65: 365-376.

\& S. P. Harrison. 2012. Climate and the evolution of serpentine endemism in California. Evolutionary Ecology 26: 1011-1023.

2014. The nature of serpentine endemism. American Journal of Botany 101: 219-224.

- \& S. Y. Strauss. 2014. The geography and ecology of plant speciation: Range overlap and niche divergence in sister species. Proceedings of the Royal Society B. 281: 20132980.

Andrew, R., K. L. Ostevik, D. P. Ebert \& L. H. Rieseberg. 2012. Adaptation with gene flow across the landscape in a dune sunflower. Molecular Ecology 21: 2078-2091.

Andrew, R. L. \& L. H. Rieseberg. 2013. Divergence is focused on few genomic regions early in speciation: incipient speciation of sunflower ecotypes. Evolution 67: 2468-2482. 
Antonovics, J. 1968. Evolution in closely adjacent plant populations V. Evolution of self-fertility. Heredity 23: 219-238.

1976. The nature of limits to natural selection. Annals of the Missouri Botanical Gardens 63: 224-247. 2006. Evolution in closely adjacent plant populations X: long-term persistence of prereproductive isolation at a mine boundary. Heredity 97: 33-37.

Armbruster, W. S. 2014. Multiple origins of serpentine-soil endemism explained by preexisting tolerance of open habitats. Proceedings of the National Academy of Sciences of the United States of America 111: 14968-14969.

Arnold, B. J., B. Lahner, J. M. DaCosta, C. M. Weisman, J. D. Hollister, D. E. Salt, K. Bomblies \& L. Yant. 2016. Borrowed alleles and convergence in serpentine adaptation. Proceedings of the National Academy of Sciences of the United States of America 113: 8320-8325.

Baack, E., M. C. Melo, L. H. Rieseberg \& D. Ortiz-Barrientos. 2015. The origins of reproductive isolation in plants. New Phytologist 207: 968-984.

Baker, H. G. 1965. Characteristics and modes of origins of weeds. Pp. 147-172. In: H. G. Baker \& G. L. Stebbins (eds.), The genetics of colonizing species. Academic Press, New York.

Baldwin, B. G. 1999. New combinations and new genera in the North American tarweeds (CompositaeMadiinae). Novon 9: 462-471.

2005. Origin of the serpentine-endemic herb Layia discoidea from the widespread L. glandulosa (Compositae). Evolution 59: 2473-2479.

2014. Origins of plant diversity in the California Floristic Province. Annual Review of Ecology Evolution and Systematics 45: 347-369.

Barraclough, T. G. \& A. P. Vogler. 2000. Detecting the geographical pattern of speciation from species-level phylogenies. American Naturalist 155: 419-434.

Bastida, J. M., P. J. Rey \& J. M. Alcántara. 2014. Plant performance and morpho-functional differentiation in response to edaphic variation in Iberian columbines: cues for range distribution? Journal of Plant Ecology-UK 7: 403-412.

Baumbach, H. \& F. H. Hellwig. 2007. Genetic differentiation of metallicolous and non-metallicolous Armeria maritima (Mill.) Willd. taxa (Plumbaginaceae) in Central Europe. Plant Systematics and Evolution 269: 245-258.

Bell, G. 2012. Evolutionary rescue and the limits of adaptation. Philosophical Transactions of the Royal Society London B Biological Sciences 368: 20120080.

Bennett, T. H., T. J. Flowers \& L. Bromham. 2013. Repeated evolution of salt-tolerance in grasses. Biological Letters 9: 20130029.

Bolukbasi, A., L. Kurt \& S. Palacio. 2016. Unravelling the mechanisms for plant survival on gypsum soils: an analysis of the chemical composition of gypsum plants from Turkey. Plant Biology 18: 271-279.

Borchsenius, F., T. Lozada \& J. T. Knudsen. 2016. Reproductive isolation of sympatric forms of the understorey palm Geonoma macrostachys in western Amazonia. Botanical Journal of the Linnean Society 182: 398-410.

Boyd, R. S. 2007. The defense hypothesis of elemental hyperaccumulation: status, challenges and new directions. Plant and Soil 293: 153-176.

— \& M. A. Wall. 2001. Responses of generalist predators fed high-Ni Melanotrichus boydi (Heteroptera: Miridae): Elemental defense against the third trophic level. American Midland Naturalist 146: 186-198. 2014. Ecology and evolution of metal-hyperaccumulator plants. Pp. 227-241. In: N. Rajakaruna, R. S. Boyd \& T. B. Harris (eds.), Plant ecology and evolution in harsh environments. Nova Science Publishers, Hauppauge, New York.

Bradshaw, A. D. 1991. The Croonian Lecture, 1991. Genostasis and the limits to evolution. Philosophical Transactions of the Royal Society London B Biological Sciences 333: 289-305. 2006. Unravelling phenotypic plasticity-why should we bother? New Phytologist 170: 644-648.

Bradshaw, H. D. 2005. Mutations in CAX1 produce phenotypes characteristic of plants tolerant to serpentine soils. New Phytologist 167: 81-88.

Brady, K. U., A. R. Kruckeberg, H. D. Bradshaw JR. 2005. Evolutionary ecology of plant adaptation to serpentine soils. Annual Review of Ecology Evolution and Systematics 36: 243-266.

Bratteler, M., M. Baltisberger \& A. Widmer. 2006. QTL analysis of intraspecific differences between two Silene vulgaris ecotypes. Annals of Botany 98:411-419.

- C. Lexer \& A. Widmer. 2006. Genetic architecture of traits associated with serpentine adaptation of Silene vulgaris. Journal of Evolutionary Biology 19: 1149-1156.

Bresowar, G. E. \& M. E. McGlaughlin. 2015. Morphological and genetic discrepancies in populations of Oreocarya paradoxa and $O$. revealii: The impact of edaphic selection on recent diversification in the Colorado Plateau. American Journal of Botany 102: 1647-1658. 
Brokaw, J. M., T. A. Johnson \& C. H. Hofsommer. 2015. Edaphic Specialization in the Cryptic Species Mentzelia monoensis (Loasaceae). Madroño 62: 88-100.

Burge, D. O. \& P. S. Manos. 2011. Edaphic ecology and genetics of the gabbro-endemic shrub Ceanothus roderickii (Rhamnaceae). Madroño 58: 1-21.

$\longrightarrow$, R. Hopkins, Y.-H. E. Tsai \& P. S. Manos. 2013. Limited hybridization across an edaphic disjunction between the gabbro-endemic shrub Ceanothus roderickii (Rhamnaceae) and the soilgeneralist Ceanothus cuneatus. American Journal of Botany 100: 1883-1895.

Burrell, A. M., A. K. Hawkins \& A. E. Pepper. 2012. Genetic analyses of nickel tolerance in a North American serpentine endemic plant, Caulanthus amplexicaulis var. barbarae (Brassicaceae). American Journal of Botany 99: 1875-1883.

Cacho, N. I. \& S. Y. Strauss. 2014. Occupation of bare habitats, an evolutionary precursor to soil specialization in plants. Proceedings of the National Academy of Sciences of the United States of America 111: 15132-15137.

— A. M. Burrell, A. E. Pepper \& S. Y. Strauss. 2014. Systematics and the evolution of serpentine tolerance in the California Jewelflowers (Streptanthus) and its allies. Molecular Phylogenetics and Evolution 72: 71-81.

Chaney, R. L., R. D. Reeves, I. A. Baklanov, T. Centofanti, C. L. Broadhurst, A. J. M. Baker, A. van der Ent \& R. J. Roseberg. 2014. Phytoremediation and phytomining: using plants to remediate contaminated or mineralized environments. Pp. 365-392. In: N. Rajakaruna, R. S. Boyd, T. B. Harris (eds.), Plant ecology and evolution in harsh environments. Nova Science Publishers, New York.

Cheeseman, J. M. 2015. The evolution of halophytes, glycophytes and crops, and its implications for food security under saline conditions. New Phytologist 206: 557-570.

Cheng, N. H., J. K. Pittman, J. B. Bronwyn, T. Shigaki \& K. D. Hirchi. 2003. The Arabidopsis cax1 mutant exhibits impaired ion homeostasis, development, and hormonal responses and reveals interplay among vacuolar transporters. Plant Cell 15: 347-364.

Cheplick, G. P. 2015. Approaches to Plant Evolutionary Ecology. Oxford University Press, New York.

Christie, P. \& M. R. Macnair. 1984. Complementary lethal factors in two North-American populations of the yellow monkey flower. Journal of Heredity 75: 510-511.

_ \& M. R. Macnair. 1987 The distribution of postmating reproductive isolating genes in populations of the yellow monkey flower, Mimulus guttatus. Evolution. 41: 571-578.

Clausen, J., D. D. Keck \& W. M. Hiesey. 1940. Experimental studies on the nature of species. I. Effect of varied environment on Western North American plants. Carnegie Institution of Washington, Washington, DC.

Crawford, D. J. 2010. Progenitor-derivative species pairs and plant speciation. Taxon 59: 1413-1423.

R. Ornduff \& M. C. Vasey. 1985. Allozyme variation within and between Lasthenia minor and its derivative species, L. maritima (Asteraceae) 72: 1177-1184.

— , J. J. Doyle, D. E. Soltis, P. S. Soltis \& J. F. Wendel. 2014. Contemporary and future studies in plant speciation, morphological/floral evolution and polyploidy: honouring the scientific contributions of Leslie D. Gottlieb to plant evolutionary biology. Philosophical Transactions of the Royal Society London B Biological Sciences 369: 20130341.

Damschen, E. I., S. P. Harrison \& J. B. Grace. 2010. Climate change effects on an endemic-rich edaphic flora: resurveying Robert H. Whittaker's Siskiyou sites (Oregon, USA). Ecology 91: 3609-3619.

—, S. P. Harrison, D. D. Ackerly, B. Fernandez-Going \& B. L. Anacker. 2012. Endemic plants on serpentine soils: Early victims or hardy survivors of climate change? Journal of Ecology 100: 1122-1130.

De Storme, N. \& A. Mason. 2014. Plant speciation through chromosome instability and ploidy change: Cellular mechanisms, molecular factors and evolutionary relevance. Current Plant Biology 1: 10-33.

Dechamps, C., N. Noret, R. Mozek, J. Escarré, C. Lefèbvre, W. Gruber, P. Meerts. 2008. Cost of adaptation to a metalliferous environment for Thlaspi caerulescens: a field reciprocal transplantation approach. New Phytologist 177: 167-177.

Dillenberger, M. S. \& J. W. Kadereit. 2013. The phylogeny of the European high mountain genus Adenostyles (Asteraceae-Senecioneae) reveals that edaphic shifts coincide with dispersal events. American Journal of Botany 100: 1171-1183.

Donovan, L. A., D. R. Rosenthal, M. Sanchez-Velenosi, L. H. Rieseberg \& F. Ludwig. 2010. Are hybrid species more fit than ancestral parent species in the current hybrid species habitats? Journal of Evolutionary Biology 23: 805-816.

Douglas, N. A., W. A. Wall, Q.-Y. (J) Xiang, W. A. Hoffmann, T. R. Wentworth, J. B. Gray \& M. G. Hohmann. 2011. Recent vicariance and the origin of the rare, edaphically specialized Sandhills lily, Lilium pyrophilum (Liliaceae): evidence from phylogenetic and coalescent analyses. Molecular Ecology 20: 2901-2915. 
Dubois, S., P.-O. Cheptou, C. Petit, P. Meerts, M. Poncelet, X. Vekemans, C. Lefèbvre \& J. Escarré. 2003. Genetic structure and mating systems of metallicolous and nonmetallicolous populations of Thlaspi caerulescens. New Phytologist 157: 633-641.

Dunning, L. T., H. Hipperson, W. J. Baker, R. K. Butlin, C. Devaux, I. Hutton, J. Igea, A. S. T. Papadopulos, X. Quan, C. M. Smadja, C. G. N. Turnbull \& V. Savolaine. 2016. Ecological speciation in sympatric palms: 1. Gene expression, selection and pleiotropy. Journal of Evolutionary Biology 29: $1472-1487$.

Edelist, C., X. Raffoux, M. Falque, C. Dillmann, D. Sicard, L. H. Rieseberg \& S. Karrenberg. 2009. Differential expression of candidate salt-tolerance genes in the halophyte Helianthus paradoxus and its glycophyte progenitors H. annuus and H. petiolaris (Asteraceae). American Journal of Botany 96: 1830-1838.

EI Mehdawi, A. F., C. F. Quinn \& E. A. Pilon-Smits. 2011. Effects of selenium hyperaccumulation on plantplant interactions: evidence for elemental allelopathy? New Phytologist 191: 120-131.

\& E. A. H. Pilon-Smits. 2012. Ecological aspects of plant selenium hyperaccumulation. Plant Biology 14: 1-10.

Ellis, A. G. \& A. E. Weis. 2005. Coexistence and differentiation of 'flowering stones': the role of local adaptation to soil microenvironment. Journal of Ecology 94: 322-335.

— A. E. Weis \& B. S. Gaut. 2006. Evolutionary radiation of 'stone plants' in the genus Argyroderma (Aizoaceae): unraveling the effects of landscape, habitat and flowering time. Evolution 60: 39-55.

Ellstrand, N. C. 2014. Is gene flow the most important evolutionary force in plants? American Journal of Botany 101: 737-753.

Ernst, W. H. O. 2006. Evolution of metal tolerance in higher plants. Forest Snow and Landscape Research 80: 251-274.

Escudero, A., S. Palacio, F. T. Maestre \& A. L. Luzuriaga. 2015. Plant life on gypsum: a review of its multiple facets. Biological Reviews 90: 1-18.

Faria, R., S. Renaut, J. Galindo, C. Pinho, J. Melo-Ferreira, M. Melo, F. Jones, W. Salzburger, D. Schluter \& R. Butlin. 2014. Advances in Ecological Speciation: an integrative approach. Molecular Ecology 23: 513-521.

Feliner, G. N., A. Izuzquiza \& A.R. Lansac. 1996. Natural and experimental hybridization in Armeria (Plumbaginaceae): A. villosa subsp. carratracensis. Plant Systematics and Evolution 201: 163-177.

Fernandez-Going, B. M., B. L. Anacker \& S. P. Harrison. 2012. Temporal variability in California grasslands: Soil type and species functional traits mediate response to precipitation. Ecology 93: 2104-2114.

— \& S. P. Harrison. 2013. Effects of experimental water addition depend on grassland community characteristics. Plant Ecology 214: 777-786.

2014. Climate change and the future of edaphic floras. Pp. 297-312. In: N. Rajakaruna, R. S. Boyd \& T. B. Harris (eds.), Plant ecology and evolution in harsh environments. Nova Science Publishers, Hauppauge, New York.

Ferris, K. G., J. P. Sexton \& J. H. Willis. 2014. Speciation on a local geographic scale: the evolution of a rare rock outcrop specialist in Mimulus. Philos. Philosophical Transactions of the Royal Society London B Biological Sciences 369: 20140001.

—, L. L. Barnett, B. K. Blackman \& J. H. Willis. 2016. The genetic architecture of local adaptation and reproductive isolation in sympatry within the Mimulus guttatus species complex. Molecular Ecology 26: 208-224.

Fine, P. V. A., I. Mesones \& P. D. Coley. 2004. Herbivores promote habitat specialization by trees in Amazonian forests. Science 305: 663-665.

—, Z. J. Miller, I. Mesones, S. Irazuzta, H. M. Appel, M. H. H. Stevens, I. Sääksjärvi, J. C. Schultz \& P. D. Coley. 2006. The growth-defense trade-off and habitat specialization by plants in Amazonian forests. Ecology 87: S150-S162.

$\longrightarrow$, F. Zapata, D. C. Daly, I. Mesones, T. M. Misiewicz, H. F. Cooper \& C. E. A. Barbosa. 2013. The importance of environmental heterogeneity and spatial distance in generating phylogeographic structure in edaphic specialist and generalist tree species of Protium (Burseraceae) across the Amazon Basin. Journal of Biogeography 40: 646-661.

Fones, H., C. A. R. Davis, A. Rico, F. Fang, J. A. C. Smith \& G.M. Preston. 2010. Metal hyperaccumulation armors plants against disease. PLOS Pathogens 6: e1001093.

Forde, M. B. \& D. G. Faris. 1962. Effect of introgression on the serpentine endemism of Quercus durata. Evolution 16: 338-347.

Freeland, J. R., P. Biss, K. F. Conrad \& J. Silvertown. 2010. Selection pressures have caused genome-wide population differentiation of Anthoxanthum odoratum despite the potential for high gene flow. Journal of Evolutionary Biology 23: 776-782. 
Friedman, J. \& J. H. Willis. 2013. Major QTLs for critical photoperiod and vernalization underlie extensive variation in flowering in the Mimulus guttatus species complex. New Phytologist 199: 571-583.

Gardner, M. \& M. R. Macnair. 2000. Factors affecting the co-existence of the serpentine endemic Mimulus nudatus Curran and its presumed progenitor, Mimulus guttatus Fischer ex DC. Biological Journal of the Linnean Society 69: 443-459.

Gil-López, M. J., J. G. Segarra-Moragues \& F. Ojeda. 2014. Population genetic structure of a sandstone specialist and a generalist heath species at two levels of sandstone patchiness across the Strait of Gibraltar. PLOS One 9: e98602.

Gill, S. S., N. A. Anjum, I. Ahmad, P. Thangavel, G. Sridevi, M. Pacheco, A. C. Duarte, S. Umar, N. A. Khan \& M. E. Pereira. 2012. Metal Hyperaccumulation and Tolerance in Alyssum, Arabidopsis and Thlaspi: An Overview. Pp. 99-137. In: N.A. Anjum, I. Ahmad, M.E. Pereira, A.C. Duarte, S. Umar, N.A. Khan (eds.), The plant family Brassicaceae: contribution towards phytoremediation. Springer Science \& Business Media, Dordrecht.

Glassmand, S. I. \& B. B. Casper. 2012. Biotic contexts alter metal sequestration and AMF effects on plant growth in soils polluted with heavy metals. Ecology 93: 1550-1559.

Going, B. M., J. Hillerislambers \& J. M. Levine. 2009. Abiotic and biotic resistance to grass invasion in serpentine annual plant communities. Oecologia 159: 839-847.

Gonzalez-Chavez, C., P. J. Harris, J. Dodd \& A. A. Meharg. 2002. Arbuscular mycorrhizal fungi confer enhanced arsenate resistance on Holcus lanatus. New Phytologist 155: 163-171.

Gottlieb, L. D. 1968. Hybridization between Arctostaphylos viscida and A. canescens in Oregon. Brittonia 20: 83-93.

2004. Rethinking classic examples of recent speciation in plants. New Phytologist 161: 71-82.

Gram, W. L., E. T. Borer, K. L. Cottingham, E. W. Seabloom, V. L. Boucher, L. Goldwasser, F. Micheli, B. E. Kendall \& R. S. Burton. 2004. Distribution of plants in a California serpentine grassland: Are rocky hummocks spatial refuges for native species? Plant Ecology 172: 159-171.

Gramlich, S., P. Sagmeister, S. Dullinger, F. Hadacek \& E. Hörandl. 2016. Evolution in situ: hybrid origin and establishment of willows (Salix L.) on alpine glacier forefields, Heredity 116: 531-541.

Grossenbacher, D. L., S. D. Veloz \& J. P. Sexton. 2014. Niche and range size patterns suggest that speciation begins in small, ecologically diverged populations in North American monkeyflowers (Mimulus spp.). Evolution 68: 1270-1280.

Hall, M. C., D. B. Lowry \& J. H. Willis. 2010. Is local adaptation in Mimulus guttatus caused by trade-offs at individual loci? Molecular Ecology 19: 2739-2753.

Harper, F. A., Smith, S. E. \& M. R. Macnair. 1997a. Where is the cost in copper tolerance in Mimulus guttatus? Testing the trade-off hypothesis. Functional Ecology 11: 764-774.

—, Smith, S. E. \& M. R. Macnair. 1997b. Can an increased copper requirement in copper-tolerant Mimulus guttatus explain the cost of tolerance? I. Vegetative phase. New Phytologist 136: 455-467

— Smith, S. E. \& M. R. Macnair. 1998. Can an increased copper requirement in copper-tolerant Mimulus guttatus explain the cost of tolerance? II. Reproductive phase. New Phytologist 140: 637-654.

Harrison, S. P. 1999. Native and alien species diversity at the local and regional scales in a Native and alien species diversity at the local and regional scales in a grazed California grassland. Oecologia 121: 99-106.

\& N. Rajakaruna (eds.). 2011. Serpentine: the evolution and ecology of a model system. University of California Press, Berkeley.

—, E. Damschen, B. Fernandez-Going, A. Eskelinen \& S. Copeland. 2015. Plant communities on infertile soils are less sensitive to climate change. Annals of Botany 116: 1017-1022.

Hayward, A. R., K. E. Coates, A. L. Galer, T. C. Hutchinson \& R. J. Emery. 2013. Chelator profiling in Deschampsia cespitosa (L.) Beauv. reveals a Ni reaction, which is distinct from the ABA and cytokinin associated response to Cd. Plant Physiology and Biochemistry 64: 84-91.

Hego, E., S. Vilain, A. Barré, S. Claverol, J.-W. Dupuy, C. Lalanne, M. Bonneu, C. Plomion, M. Mench. 2016. Copper stress-induced changes in leaf soluble proteome of $\mathrm{Cu}$-sensitive and tolerant Agrostis capillaris L. populations. Proteomics 16: 1386-1397.

Henry, L. P., R. H. B. Watson \& B. K. Blackman. 2014. Transitions in photoperiodic flowering are common and involve few loci in wild sunflowers (Helianthus; Asteraceae). American Journal of Botany 101: 1748-1758.

Hereford, J. 2009. A quantitative survey of local adaptation and fitness trade-offs. American Naturalist 173: 579-588.

Hipperson, H., L. T. Dunning, W. J. Baker, R. K. Butlin, I. Hutton, A. S. T. Papadopulos, C. M. Smadja, T. C. Wilson, C. Devaux \& V. Savolainen, V. 2016. Ecological speciation in sympatric palms: 2. Preand post-zygotic isolation, Journal of Evolutionary Biology 29: 2143-2156. 
Hoban, S., J. L. Kelley, K. E. Lotterhos, M. F. Antolin, G. Bradburd, D. B. Lowry, M. L. Poss, L. K. Reed, A. Storfer \& M. C. Whitlock. 2016. Finding the genomic basis of local adaptation: pitfalls, practical solutions, and future directions. American Naturalist 188: 379-397.

Hopkins, R. 2013. Reinforcement in plants. New Phytologist 197: 1095-1103.

Hörger, A. C., H. N. Fones \& G. M. Preston. 2013. The current status of the elemental defense hypothesis in relation to pathogens. Frontiers in Plant Science 4: 1-11.

Huang, X. \& D. E. Salt. 2016. Plant ionomics: from elemental profiling to environmental adaptation. Molecular Plant 9: 787-797.

Hunter, B. \& K. Bomblies. 2010. Progress and promise in using Arabidopsis to study adaptation, divergence, and speciation. Arabidopsis Book 8: e0138.

Jurjavcic, N. L., S. P. Harrison \& A. T. Wolf. 2002. Abiotic stress, competition, and the distribution of the native annual grass Vulpia microstachys in a mosaic environment. Oecologia 130: 555-562.

Kane, N. C. 2009. Comparative genomic and population genetic analyses indicate highly porous genomes and high levels of gene flow between divergent Helianthus species. Evolution 63: 2061-2075.

Kaplan, Z. 1998. Relict serpentine populations of Knautia arvensis s. 1. (Dipsacaceae) in the Czech Republic and an adjacent area of Germany. Preslia 70: 21-31.

Kay, K. M., K. L. Ward, L. R. Watt \& D.W. Schemske. 2011. Plant Speciation. Pp. 71-96. In: S. P. Harrison \& N. Rajakaruna (eds.), Serpentine: the evolution and ecology of a model system. University of California Press, Berkeley.

Kazakou, E., P.G. Dimitrakopoulos, A.J. Baker, R.D. Reeves \& A.Y. Troumbis. 2008. Hypotheses, mechanisms and trade-offs of tolerance and adaptation to serpentine soils: from species to ecosystem level. Biological Reviews 83: 495-508.

Klein, J. T. \& J. W. Kadereit. 2015. Phylogeny, biogeography and evolution of edaphic association in the European oreophytes Sempervivum and Jovibarba (Crassulaceae). International Journal of Plant Sciences 176: 44-71.

Kolář, F., T. Fér, M. Štech, P. Trávníček, E. Dušková, P. Schönswetter \& J. Suda. 2012. Bringing together evolution on serpentine and polyploidy: spatiotemporal history of the diploid-tetraploid complex of Knautia arvensis (Dipsacaceae). PLoS ONE 7: e39988.

—, M. Dortová, J. Lepš, M. Pouzar, A. Krejčová \& M. Štech. 2014. Serpentine ecotypic differentiation in a polyploid plant complex: shared tolerance to $\mathrm{Mg}$ and $\mathrm{Ni}$ stress among di- and tetraploid serpentine populations of Knautia arvensis (Dipsacaceae). Plant and Soil 374: 435-447.

Krahulcová, A. \& J. Štěpánková. 1998. Serpentine and polyploid differentiation within Galium pumilum agg. (Rubiaceae) in Eastern C. Europe. Folia Geobotanica 33: 87-102.

Kruckeberg, A. R. 1951. Intraspecific variability in the response of certain native plant species to serpentine soil. American Journal of Botany 38: 408-419.

1954. The ecology of serpentine soils. III. Plant species in relation to serpentine soils. Ecology 35 : 267-274.

1986. An essay: The stimulus of unusual geologies for plant speciation. Systematic Botany 11: 455-463.

1992. Plant life of western North American ultramafics. Pp. 31-73. In: B. A. Roberts \& J. Proctor (eds.), The ecology of areas with serpentinized rocks. Springer Netherlands. Dordrecht.

Lai, Z., T. Nakazato, M. Salmaso, J. M. Burke, S. Tang, S. J. Knapp \& L. H. Rieseberg. 2005. Extensive chromosomal repatterning and the evolution of sterility barriers in hybrid sunflower species. Genetics. 171: 291-303.

Lau, J. A., A. C. McCall, K. F. Davies, J. K. McKay \& J. W. Wright. 2008. Herbivores and edaphic factors constrain the realized niche of a native plant. Ecology 89: 754-762.

Leimu, R. \& M. Fischer. 2008. A meta-analysis of local adaptation in plants. PLoS ONE 3(12): e4010.

Leinonen, P. H., D. L. Remington, J. Leppälä \& O. Savolainen. 2013. Genetic basis of local adaptation and flowering time variation in Arabidopsis lyrata. Molecular Ecology 22: 709-723.

Levin, D. A. 1993. Local speciation in plants: the rule not the exception. Systematic Botany 18: 197-208. 2001. The recurrent origin of plant races and species. Systematic Botany 26: 197-204.

2009. Flowering-time plasticity facilitates niche shifts in adjacent populations. New

Lexer, C., M. E. Welch, J. L. Durphy \& L. H. Rieseberg. 2003. Natural selection for salt tolerance quantitative trait loci (QTLs): Implications for the origin of Helianthus paradoxus, a diploid hybrid species. Molecular Ecology 12: 1225-1235.

— Z Z. Lai \& L. H. Rieseberg. 2004. Candidate gene polymorphisms associated with salt tolerance in wild sunflower hybrids: implications for the origin of Helianthus paradoxus, a diploid sunflower hybrid species. New Phytologist 161: 225-233.

Loarie, S. R., B. E. Carter, K. Hayhoe, S. McMahon, R. Moe, C. A. Knight \& D. D. Ackerly. 2008. Climate Change and the Future of California's Endemic Flora. PLOS One 3: e2502. 
Lowry, D. B., R. C. Rockwood \& J. H. Willis. 2008. Ecological reproductive isolation of coast and inland races of Mimulus guttatus. Evolution 62: 2196-2214.

- M. C. Hall, D. E. Salt, J. H. Willis. 2009. Genetic and physiological basis of adaptive salt tolerance divergence between coastal and inland Mimulus guttatus. New Phytologist 183: 776-788.

— \& J. H. Willis. 2010. A widespread chromosomal inversion polymorphism contributes to a major life history transition, local adaptation, and reproductive isolation. PLOS Biol. 8: e1000500.

2012. Ecotypes and the controversy over stages in the formation of new species. Biological Journal of the Linnean Society 106: 241-257.

— C. C. Sheng, Z. Zhu, T. E. Juenger \& B. C. Lahner. 2012. Mapping of ionomic traits in Mimulus guttatus reveals Mo and Cd QTLs that colocalize with MOT1 homologues. PLOS One 7: e30730.

Macnair, M R. 1983. The genetic control of copper tolerance in the yellow monkey flower, Mimulus guttatus. Heredity 50: 283-293.

— \& P. Christie. 1983. Reproductive isolation as a pleiotropic effect of copper tolerance in Mimulus guttatus? Heredity 50: 295-302.

_ V. E. Macnair \& B. E. Martin. 1989. Adaptive speciation in Mimulus: an ecological comparison of M. cupriphilus with its presumed progenitor, M. guttatus. New Phytologist 112: 269-279.

_ S. E. Smith \& Q. J. Cumbes. 1993. Heritability and distribution of variation in degree of copper tolerance in Mimulus guttatus at Copperopolis, California. Heredity: 71: 445-455.

— \& M. Gardner. 1998. The evolution of edaphic endemics. Pp. 157-171. In: D. J. Howard \& S. H. Berlocher (eds.), Endless forms: species and speciation. Oxford University Press, New York.

Maestri, E., M. Marmiroli, G. Visioli \& N. Marmiroli. 2010. Metal tolerance and hyperaccumulation: Costs and trade-offs between traits and environment. Environmental and Experimental Botany 68: 1-13.

Mandáková, T., V.Singh, U. Krämer \& M. A. Lysak. 2015. Genome structure of the heavy metal hyperaccumulator Noccaea caerulescens and its stability on metalliferous and nonmetalliferous soils. Plant Physiology 169: 674-689.

Marsden-Jones, E. M. \& W. B. Turrill. 1938. Transplant experiments of the British Ecological Society at Potterne, Wiltshire. Summary of results: 1928-1937. Journal of Ecology 26: 380-389.

Martin, N. H., A. C. Bouck \& M. L. Arnold. 2006. Detecting adaptive trait introgression between Iris fulva and $I$. brevicaulis in highly selective field conditions. Genetics 172: 2481-2489.

Mason, H. L. 1946a. The edaphic factor in narrow endemism. I. The nature of environmental influences. Madroño 8: 209-226.

1946b. The edaphic factor in narrow endemism. II. The geographic occurrence of plants of highly restricted patterns of distribution, Madroño 8: 241-257.

Mayer, M. S. \& P. S. Soltis. 1994. The evolution of serpentine endemics: A chloroplast DNA phylogeny of the Streptanthus glandulosus complex (Cruciferae). Systematic Botany 19: 557-574.

— \& P. S. Soltis. 1999. Intraspecific phylogeny analysis using ITS sequences: Insights from studies of the Streptanthus glandulosus complex (Cruciferae). Systematic Botany 24: 47-61.

Meindl, G. A. \& T. -L. Ashman. 2013. The effects of aluminum and nickel in nectar on the foraging behavior of bumblebees. Environmental Pollution 177: 78-81.

\& floral visitation rate. Journal of Chemical Ecology 40: 128-135.

— D. J. Bain \& T.-L. Ashman. 2014. Nickel accumulation in leaves, floral organs and rewards varies by serpentine soil affinity. AoB PLANTS 6: plu036.

\& T. -L. Ashman. 2015. Effects of floral metal accumulation on floral visitor communities: Introducing the elemental filter hypothesis. American Journal of Botany 102: 379-389.

Melo, M. C., A. Grealy, B. Brittain, G. M. Walter \& D. Ortiz-Barrientos. 2014. Strong extrinsic reproductive isolation between parapatric populations of an Australian groundsel. New Phytologist 203: 323-334.

Mengoni, A., C. Gonnelli, F. Galardi, R. Gabbrielli \& M. Bazzicalupo. 2001. Genetic diversity of heavy metal tolerant populations in Silene paradoxa L. (Caryophyllaceae): a chloroplast microsatellite analysis. Molecular Ecology 10: 1909-1916.

—, A. J. M. Baker, M. Bazzicalupo, R. D. Reeves, N. Adigüzel, E. Chianni, F. Galardi, R. Gabbrielli \& C. Gonnelli. 2003a. Evolutionary dynamics of nickel hyperaccumulation in Alyssum revealed by its nrDNA analysis. New Phytologist 159: 691-699.

— C. Gonnelli, E. Brocchini, F. Galardi, S. Pucci, R. Gabbrielli \& M. Bazzicalupo. 2003 b. Chloroplast genetic diversity and biogeography in the serpentine endemic Ni-hyperaccumulator Alyssum bertolonii. New Phytologist 157: 349-356.

Miglia, K. J. 2007. Genotype, soil type, and locale effects on reciprocal transplant vigor, endophyte growth, and microbial functional diversity of a narrow sagebrush hybrid zone in Salt Creek Canyon, Utah. American Journal of Botany 94: 425-436. 
Milla, R., A. Escudero \& J. M. Iriondo. 2011. Congruence between geographic range distribution and local competitive ability of two Lupinus species. American Journal of Botany 98: 1456-1464.

Moore, A. J. \& J. W. Kadereit. 2013. The evolution of substrate differentiation in Minuartia series Laricifoliae (Caryophyllaceae) in the European Alps: In situ origin or repeated colonization? American Journal of Botany 100: 2412-2425.

- D. Merges \& J. W. Kadereit. 2013. The origin of the serpentine endemic Minuartia laricifolia subsp. ophiolitica by vicariance and competitive exclusion, Molecular Ecology 22: 2218-2231.

Moore, K. A. \& S. C. Elmendorf. 2011. Plant competition and facilitation in systems with strong environmental gradients. Pp. 223-236. In: S. P. Harrison \& N. Rajakaruna (eds.), Serpentine: the evolution and ecology of a model system. University of California Press, Berkeley.

Moore, M. J., J. F. Mota, N. A. Douglas, H. F. Olvera \& H. Ochoterena. 2014. The ecology, assembly, and evolution of gypsophile floras. Pp. 97-128. In: N. Rajakaruna, R. S. Boyd \& T. B. Harris (eds.), Plant ecology and evolution in harsh environments. Nova Science Publishers, Hauppauge, New York.

Moray, C., E. W. Goolsby \& L. Bromham. 2016. The phylogenetic association between salt tolerance and heavy metal hyperaccumulation in angiosperms. Evolutionary Biology 43: 119-130.

Mousset, M., P. David, C. Petit, J. Pouzadoux, C. Hatt. E. Flaven, O. Ronce \& A. Mignot. 2016. Lower selfing rates in metallicolous populations than in non-metallicolous populations of the pseudometallophyte Noccaea caerulescens (Brassicaceae) in Southern France. Annals of Botany 117: 507-519.

Moyle, L.C., M. Levine, M. L. Stanton \& J. W. Wright. 2012. Hybrid sterility over tens of meters between ecotypes adapted to serpentine and non-serpentine soils. Evolutionary Biology 39: 207-218.

Nichols, M.K. \& McNeilly, T. 1982. The possible polyphyletic origin of copper tolerance in Agrostis tenuis (Gramineae). Plant Systematics and Evolution 140: 109-117.

Nosil, P. \& D. Schluter. 2011. The genes underlying the process of speciation. Trends in Ecology and Evolution 26: 160-167.

2012. Ecological Speciation. Oxford University Press, Oxford.

Nyberg Berglund, A. B., S. Dahlgren \& A. Westerbergh. 2004. Evidence for parallel evolution and sitespecific selection of serpentine tolerance in Cerastium alpinum during the colonization of Scandinavia. New Phytologist 161: 199-209.

O'Dell, R. E. \& N. Rajakaruna. 2011. Intraspecific variation, plant adaptation, and evolution. Pp. 71-96. In: S.P. Harrison \& N. Rajakaruna (eds.), Serpentine: the evolution and ecology of a model system. University of California Press, Berkeley.

2014. Conservation and restoration of chemically extreme edaphic endemic flora in the western US. Pp. 3313-3364. In: N. Rajakaruna, R. S. Boyd, T. B. Harris (eds.), Plant ecology and evolution in harsh environments. Nova Science Publishers, New York.

Olko, A., A. Abratowska, J. Żyłkowska, M. Wierzbicka \& A. Tukiendorf. 2008. Armeria maritima from a calamine heap-Initial studies on physiologic-metabolic adaptations to metal-enriched soil. Ecotoxicology and Environmental Safety 69: 209-218.

Ornduff, R. 1965. Ornithocoprophilous endemism in Pacific Basin angiosperms. Ecology 46: 864-867.

Ortiz-Barrientos, D., A. Grealy \& P. Nosil. 2009. The genetics and ecology of reinforcement: implications for the evolution of prezygotic isolation in sympatry and beyond. Annals of the New York Academy of Sciences 1168: 156-182.

Ostevik, K. L., B. T. Moyers, G. L. Owens \& L. H. Rieseberg. 2012. Parallel Ecological Speciation in Plants? International Journal of Ecology 939862.

R. L. Andrew, S. P. Otto \& L. H. Rieseberg. 2016. Multiple reproductive barriers separate recently diverged sunflower ecotypes. Evolution 70: 2322-2335.

Palacio, S., A. Escudero, G. Montserrat-Martí, M. Maestro, R. Milla \& M. J. Albert. 2007. Plants living on gypsum: beyond the specialist model. Annals of Botany 99: 333-343.

—, D. Johnson, A. Escudero \& G. Montserrat-Martí. 2012. Root colonisation by AM fungi differs between gypsum specialist and non-specialist plants: Links to the gypsophile behavior. Journal of Arid Environments 76: 128-132.

— J. Azorín, G. Montserrat-Martí \& J. P. Ferrio. 2014. The crystallization water of gypsum rocks is a relevant water source for plants. Nature Communications 5: 4660; doi:https://doi.org/10.1038 /ncomms5660.

Palacio-López, K., B. Beckage, S. Scheiner \& J. Molofsky. 2015. The ubiquity of phenotypic plasticity in plants: a synthesis. Ecology and Evolution 5: 3389-3400.

Palm, E., K. Brady \& E. Van Volkenburgh. 2012. Serpentine tolerance in Mimulus guttatus does not rely on exclusion of magnesium. Functional Plant Biology 39: 679-688. 
\& E. Van Volkenburgh. 2014. Physiological adaptations of plants to serpentine soil. Pp. 129-148. In: N. Rajakaruna, R. S. Boyd, T. B. Harris (eds.), Plant ecology and evolution in harsh environments. Nova Science Publishers, Hauppauge, New York.

Papadopulos, A. S. T., W. J. Baker, D. Crayn, R. K. Butlin, R. G. Kynast, I. Hutton \& V. Savolainen. 2011. Speciation with gene flow on Lord Howe Island. Proceedings of the National Academy of Sciences of the United States of America 108: 13188-13193.

Parejo-Farnés, C., R. G. Albaladejo, J. Arroyo \& A. Aparicio. 2013. A phylogenetic hypothesis for Helianthemum (Cistaceae) in the Iberian Peninsula. Botanica Complutensis 37: 83-92.

Paris, C. A. \& M. D. Windham. 1988. A biosystematic investigation of the Adiantum pedatum complex in eastern North America. Systematic Botany 13: 240-255.

1991. Adiantum viridimontanum, a new maidenhair fern in eastern North America. Rhodora 93: 105-122.

Partridge, L. \& R. Sibly. 1991. Constraints in the evolution of life histories. Philosophical Transactions of the Royal Society London, B 332: 3-13.

Parys, E., W. Wasilewska, M. Siedlecka, M. Zienkiewicz, A. Drożak \& E. Romanowska. 2014. Metabolic responses to lead of metallicolous and nonmetallicolous populations of Armeria maritima. Archives of Environmental Contamination and Toxicology 67: 565-577.

Paule, J., F. Kolář \& C. Dobeš. 2015. Arctic-alpine and serpentine differentiation in polyploid Potentilla crantzii. Preslia 87: 195-215.

Paun, O., B. Turner, E. Trucchi, J. Munzinger, M. W. Chase \& R. Samuel. 2016. Processes Driving the Adaptive Radiation of a Tropical Tree (Diospyros, Ebenaceae) in New Caledonia, a Biodiversity Hotspot. Systematic Biology 65: 212-227.

Pauwels, M., P. Saumitou-Laprade, A.C. Holl, D. Petit \& I. Bonnin. 2005. Multiple origin of metallicolous populations of the pseudometallophyte Arabidopsis halleri (Brassicaceae) in central Europe: the cpDNA testimony. Molecular Ecology 14: 4403-4414.

Pepper, A. E. \& L. E. Norwood. 2001. Evolution of Caulanthus amplexicaulis var. barbarae (Brassicaceae), a rare serpentine endemic plant: a molecular phylogenetic perspective. American Journal of Botany 88 : 1479-1489.

Peterson, M. L., K. J. Rice \& J. P Sexton. 2013. Niche partitioning between close relatives suggests tradeoffs between adaptation to local environments and competition. Ecology and Evolution 3: 512-522.

Pettengill, J. B. \& D. A. Moeller. 2012. Phylogeography of speciation: allopatric divergence and secondary contact between outcrossing and selfing Clarkia. Molecular Ecology 21: 4578-4592.

Pfennig, K. S. \& D. W. Pfennig. 2009. Character displacement: ecological and reproductive responses to a common evolutionary problem. The Quarterly Review of Biology 84: 253-276.

Pope, N., M. Fong, R. S. Boyd \& N. Rajakaruna. 2014. The role of elevation and soil chemistry in the distribution and ion accumulation of floral morphs of Streptanthus polygaloides Gray (Brassicaceae), a Californian nickel hyperaccumulator. Plant Ecology and Diversity 7: 1-39.

Porter, S. S., P. L. Chang, C. A. Conow, J. P. Dunham, M. L. Friesen. 2017. Association mapping reveals novel serpentine adaptation gene clusters in a population of symbiotic Mesorhizobium. The ISME Journal 11: 248-262

Powell, K. I. \& T. M. Knight. 2009. Effects of nutrient addition and competition on biomass of five Cirsium species (Asteraceae), including a serpentine endemic. International Journal of Plant Sciences 170: 918-925.

Quinn, C. F., J. L. Freeman, R. J. B. Reynolds, J. J. Cappa, S. C. Fakra, M. A. Marcus, S. D. Lindblom, E. K. Quinn, L. E. Bennett \& E. A. H Pilon-Smits. 2010. Selenium hyperaccumulation offers protection from cell disruptor herbivores. BMC Ecology 10: 1-11.

, C. N. Prins, J. L. Freeman, A. M. Gross, L. J. Hantzis, R. J. B. Reynolds, S.Yang, P. A. Covey, G. S. Bañuelos, I. J. Pickering, S. C. Fakra, M. A. Marcus, H. S. Arathi, \& E. A. H. Pilon-Smits. 2011a. Selenium accumulation in flowers and its effects on pollination. New Phytologist 192: 727-737.

, K. A. Wyant, A. L. Wangeline, J. Shulman, M. L. Galeas, J. R. Valdez, J. R. Self, M. W. Paschke \& E. A. H. Pilon-Smits. 2011b. Enhanced decomposition of selenium hyperaccumulator litter in a seleniferous habitat — evidence for specialist decomposers? Plant and Soil 341: 51-61.

Qureshi, J. A., D. A. Thurman, K. Hardwick, H. A. Collin. 1985. Uptake and accumulation of zinc, lead and copper in zinc and lead tolerant Anthoxanthum odoratum L. New Phytologist 100: 429-434.

Rajakaruna, N. 2003. Edaphic differentiation in Lasthenia: A model for studies in evolutionary ecology. Madrono 50: 34-40.

2004. The edaphic factor in the origin of species. International Geology Review 46: 471-478.

, M. Y. Siddiqi, J. Whitton, B. A. Bohm \& A. D. M. Glass. 2003a. Differential responses to $\mathrm{Na}^{+} / \mathrm{K}^{+}$ and $\mathrm{Ca}^{2+} / \mathrm{Mg}^{2+}$ in two edaphic races of the Lasthenia californica (Asteraceae) complex: A case for parallel evolution of physiological traits. New Phytologist 157: 93-103. 
G. E. Bradfield, B. A. Bohm \& J. Whitton. 2003b. Adaptive differentiation in response to water stress by edaphic races of Lasthenia californica (Asteraceae). International Journal of Plant Sciences 164: 371-376. , Baldwin, B. G., R. Chan, A. M. Desrochers, B. A. Bohm, \& J. Whitton. 2003c. Edaphic races and phylogenetic taxa in the Lasthenia californica complex (Asteraceae: Heliantheae): An hypothesis of parallel evolution. Molecular Ecology 12: 1675-1679.

- \& J. Whitton. 2004. Trends in the evolution of edaphic specialists with an example of parallel evolution in the Lasthenia californica complex. Pp. 103-110. In: Q. C. B. Cronk, J. Whitton, R. Ree \& I. E. P. Taylor (eds.), Plant adaptation: molecular genetics and ecology. NRC Research Press, Ottawa.

— R. S. Boyd \& T. B. Harris. 2014. Synthesis and future directions: What have harsh environments taught us about ecology, evolution, conservation and restoration. Pp. 393-409. In: N. Rajakaruna, R. S. Boyd \& T. B. Harris (eds.), Plant ecology and evolution in harsh environments. Nova Science Publishers, Inc., NY.

Rascio, N. \& F. Navari-Izzo. 2011. Heavy metal hyperaccumulating plants: how and why do they do it? And what makes them so interesting? Plant Science 180: 169-181.

Raven, P. H. 1964. Catastrophic selection and edaphic endemism. Evolution 18: 336-338.

Renaut, S., C. J. Grassa, S. Yeaman, Z. Lai, N. K. Kane, B. T. Moyers, J. E. Bowers, J. M. Burke \& L. H. Rieseberg. 2013. Genomic islands of divergence are not affected by geography of speciation in sunflowers. Nature Communications 1827: doi:https://oi.org/10.1038/ncomms2833.

Rice, K. 1989. Competitive interactions in California annual grasslands. Pp. 59-72. In: L. F. Huenneke \& H. A. Mooney (eds.), Grassland structure and function: California annual grassland. Kluwer, Dordrecht.

Roda, F., L. Ambrose, G. M. Walter, G,. H. L. Liu, L. Schaul, A. Lowe, P. B. Pelser, P. Prentis, L. H. Rieseberg \& D. Ortiz-Barrientos. 2013. Genomic evidence for the parallel evolution of coastal forms in the Senecio lautus complex. Molecular Ecology 22: 2941-2952.

Roux, C., V. Castric, M. Pauwels, S. I. Wright, P. Saumitou-Laprade \& X. Vekemans. 2011. Does speciation between Arabidopsis halleri and Arabidopsis lyrata coincide with major changes in a molecular target of adaptation? PLoS ONE 6: e26872.

Roy, S. J., E. J. Tucker \& M. Tester. 2011. Genetic analysis of abiotic stress tolerance in crops. Current Opinion in Plant Biology 14: 232-239.

Rozema, J. \& H. Schat. 2013. Salt tolerance of halophytes, research questions reviewed in the perspective of saline agriculture. Environmental and Experimental Botany 92: 83-95.

Sambatti, J. B. \& K. J. Rice. 2007. Functional ecology of ecotypic differentiation in the Californian serpentine sunflower (Helianthus exilis). New Phytologist 175: 107-119.

Sánchez, A. M., P. Alonso-Valiente, M. J. Albert \& A. Escudero. 2017. How might edaphic specialists in gypsum islands respond to climate change? Reciprocal sowing experiment to infer local adaptation and phenotypic plasticity. Annals of Botany 120: 135-146.

Saslis-Lagoudakis, C. H., C. Moray \& L. Bromham. 2014. Evolution of salt tolerance in angiosperms: a phylogenetic approach. Pp. 77-95. In: N. Rajakaruna, R. S. Boyd \& T. B. Harris (eds.), Plant ecology and evolution in harsh environments. Nova Science Publishers, Hauppauge, New York.

Savolainen, V., M.-C. Anstett, C. Lexer, I. Hutton, J. J. Clarkson, M. V. Norup, M. P. Powell, D. Springate, N. Salamin \& W. J. Baker. 2006. Sympatric speciation in palms on an oceanic island. Nature 441: 210-213.

Schechter, S. P. \& T. D. Bruns. 2008. Serpentine and non-serpentine ecotypes of Collinsia sparsiflora associate with distinct arbuscular mycorrhizal fungal assemblages. Molecular Ecology 17: 3198-3210.

- \& T. D. Bruns. 2013. A common garden test of host-symbiont specificity supports a dominant role for soil type in determining AMF assemblage structure in Collinsia sparsiflora. PLOS One 8: e55507.

\& S. Branco. 2014. The ecology and evolution of mycorrhizal fungi in extreme soils. Pp. 33-52. In: N. Rajakaruna, R. S. Boyd \& T. B. Harris (eds.), Plant ecology and evolution in harsh environments. Nova Science Publishers, New York.

Schemske, D. W. 2010. Adaptation and the origin of species. American Naturalist 176: S4-S25.

Schiavon, M. \& E. A. H. Pilon-Smits. 2017. The fascinating facets of plant selenium accumulation biochemistry, physiology, evolution and ecology. New Phytologist 213: 1582-1596.

Schmickl, R. \& M. A. Koch. 2011. Arabidopsis hybrid speciation processes. Proceedings of the National Academy of Sciences of the United States of America 108: 14192-14197.

Schneider, A. C., W. A. Freyman, C. M. Guilliams, Y. P. Springer \& B. G. Baldwin. 2016. Pleistocene radiation of the serpentine-adapted genus Hesperolinon and other divergence times in Linaceae (Malpighiales). American Journal of Botany 103: 221-232.

Searcy, K. B. \& D. L. Mulcahy. 1985. Pollen selection and the gametophytic expression of metal tolerance in Silene dioica (caryophyllaceae) and Mimulus guttatus (Scrophulariaceae). American Journal of Botany 72: $1700-1706$. 
\& M. R. Macnair. 1990. Differential seed production in Mimulus guttatus Fisch, ex DC in response to increasing concentrations of copper in the pistil by pollen from copper tolerant and sensitive sources. Evolution 44: 1424-1435.

\& M. R. Macnair. 1993. Developmental selection in response to environmental conditions of the maternal parent in Mimulus guttatus. Evolution 47: 13-24.

Selby, J. P., A. L. Jeong, K. Toll, K. M. Wright, D. B. Lowry. 2014. Methods and discoveries in the pursuit of understanding the genetic basis of adaptation to harsh environments in Mimulus. Pp. 243-265. In: N. Rajakaruna, R. S. Boyd \& T. B. Harris (eds.), Plant ecology and evolution in harsh environments. Nova Science Publishers, New York.

Shimizu-Inatsugi, R., A. Terada, K. Hirose, H. Kudoh, J. Sese \& K. K. Shimizu. 2016. Plant adaptive radiation mediated by polyploid plasticity in transcriptomes. Molecular Ecology 26: 193-207.

Silvertown, J., C. Servaes, P. Biss \& D. Macleod. 2005. Reinforcement of reproductive isolation between adjacent populations in the Park Grass Experiment. Heredity 95: 198-205.

— P. Poulton, E. Johnston, G. Edwards, M. Heard \& P. M. Biss. 2006. The Park Grass Experiment 1856-2006: its contribution to ecology. Journal of Ecology 94: 801-814.

Slovák, M., J. Kučera, P. Turis \& J. Zozomová-Lihová. 2012. Multiple glacial refugia and postglacial colonization routes inferred for a woodland geophyte, Cyclamen purpurascens: patterns concordant with the Pleistocene history of broadleaved and coniferous tree species. Biological Journal of the Linnean Society: 105: 741-760.

Smith, S. E. \& M. R. Macnair. 1998. Hypostatic modifiers cause variation in degree of copper tolerance in Mimulus guttatus. Heredity 80: 760-768.

Sobel, J. M. 2014. Ecogeographic isolation and speciation in the genus Mimulus. American Naturalist 184: $565-579$.

Sobczyk, M. K., J. A. C. Smith, A. J. Pollard \& D. A. Filatov. 2017. Evolution of nickel hyperaccumulation and serpentine adaptation in the Alyssum serpyllifolium species complex. Heredity 118: 31-41.

Soltis, D. E., P. S. Soltis \& J. A. Tate. 2004. Advances in the study of polyploidy since plant speciation. New Phytologist 161: 173-191.

Southworth, D., L. E. Tackaberry \& H. B. Massicotte. 2014. Mycorrhizal ecology on serpentine soils. Plant Ecology and Diversity 7: 445-455.

Spasojevic, M. J., E. I. Damschen \& S. P. Harrison. 2014. Patterns of seed dispersal syndromes on serpentine soils: examining the roles of habitat patchiness, soil infertility and correlated functional traits. Plant Ecology and Diversity 7: 401-410.

Springer, Y. P. 2007. Clinal resistance structure and pathogen local adaptation in a serpentine flax-flax rust interaction. Evolution 61: 1812-1822.

2009. Edaphic quality and plant-pathogen interactions: Effects of soil calcium on fungal infection of a serpentine flax. Ecology 90: 1852-1862.

Strasburg, J. L., N. A. Sherman, K. M. Wright, L. C. Moyle, J. H. Willis \& L. H. Rieseberg. 2012. What can patterns of differentiation across plant genomes tell us about adaptation and speciation? Philosophical Transactions of the Royal Society London B Biological Sciences 367: 364-373.

Strauss, S. Y. \& R. S. Boyd. 2011. Herbivory and other cross-kingdom interactions on harsh soils. Pp. 181199. In: S. P. Harrison \& N. Rajakaruna (eds.), Serpentine: the evolution and ecology of a model system. University of California Press, Berkeley.

\& N. I. Cacho. 2013. Nowhere to run, nowhere to hide: The importance of enemies and apparency in adaptation to harsh soil environments. American Naturalist 182: E1-E14.

Sun, G. \& P. Schliekelman. 2011. A genetical genomics approach to genome scans increases power for QTL mapping, Genetics 187: 939-953.

Thrall, P. H., M. E. Hochberg, J. J. Burdon \& J. D. Bever. 2007. Coevolution of symbiotic mutualists and parasites in a community context. Trends in Ecology \& Evolution 22: 120-126.

- J. D. Bever \& J. F. Slattery. 2008. Rhizobial mediation of Acacia adaptation to soil salinity: evidence of underlying trade-offs and tests of expected patterns. Journal of Ecology 96: 746-755.

Tiffin, P. \& J Ross-Ibarra. 2014. Advances and limits of using population genetics to understand local adaptation. Trends in Ecology \& Evolution 29: 673-680.

Turesson, G. 1922. The species and the variety as ecological units. Hereditas 3: 100-113.

Turner, T. L., E. J. von Wettberg, S. V. Nuzhdin. 2008. Genomic analysis of differentiation between soil types reveals candidate genes for local adaptation in Arabidopsis lyrata. PLOS One 3: e3183.

— E. C. Bourne, E. J. Von Wettberg, T. T. Hu, S. V. Nuzhdin. 2010. Population resequencing reveals local adaptation of Arabidopsis lyrata to serpentine soils. Nature Genetics 42: 260-263.

Twyford, A.D. \& J. Friedman. 2015. Adaptive divergence in the monkey flower Mimulus guttatus is maintained by a chromosomal inversion. Evolution 69: 1476-1486. 
Valladares, F., S. Matesanz, F. Guilhaumon, M. B. Araújo, L. Balaguer, M. Benito-Garzón, W. Cornwell, E. Gianoli, M. van Kleunen, D. E. Naya, A. B. Nicotra, H. Poorter \& M. A. Zavala. 2014. The effects of phenotypic plasticity and local adaptation on forecasts of species range shifts under climate change. Ecology Letters 17: 1351-1364.

Vallano, D. M., P. C. Selmants \& E. S. Zavaleta. 2012. Simulated nitrogen deposition enhances the performance of an exotic grass relative to native serpentine grassland competitors. Plant Ecology 213: 1015-1026.

Vamosi, J. C., W. S. Armbruster \& S. S. Renner. 2014. Evolutionary ecology of specialization: insights from phylogenetic analysis. Proceedings of the Royal Society B: Biological Sciences 281: 20142004.

van der Niet, T. \& S. D. Johnson. 2009. Patterns of plant speciation in the Cape floristic region, Molecular Phylogenetics and Evolution 51: 85-93.

van Hoof, N. A. L. M., V. H. Hassinen, H. W. J. Hakvoort, K. F. Ballintijn, H. Schat, J. A.C. Verkleij, W. H.O. Ernst, S. O. Karenlampi \& A. I. Tervahauta. 2001. Enhanced copper tolerance in Silene vulgaris (Moench) Garcke populations from copper mines is associated with increased transcript levels of a $2 b-$ type metallothionein gene. Plant Physiology 126: 1519-1526.

Van Nuland, M. E. 2016. Plant-soil feedbacks: connecting ecosystem ecology and evolution. Functional Ecology 30: 1032-1042.

Van Zandt, P. A. 2007. Plant defense, growth, and habitat: a comparative assessment of constitutive and induced resistance. Ecology 88: 1984-1993.

Vekemans, X. \& C. Lefèbvre. 1997. On the evolution of heavy-metal tolerant populations in Armeria maritima: evidence from allozyme variation and reproductive barriers. Journal of Evolutionary Biology 10: 175-191.

Venables, A. V. \& D. A. Wilkins. 1978. Salt tolerance in pasture grasses. New Phytologist 80: 613-622.

Verbruggen, N., C. Hermans \& H. Schat. 2009. Molecular mechanisms of metal hyperaccumulation in plants. New Phytologist 181: 759-776.

Via, S. 2009. Natural selection in action during speciation. Proceedings of the National Academy of Sciences of the United States of America 106: 9939-9946.

von Wettberg, E. J. \& J. W. Wright. 2011. Genomic approaches to understanding adaptation. Pp. 139-153. In: S.P. Harrison \& N. Rajakaruna (eds.), Serpentine: the evolution and ecology of a model system. University of California Press, Berkeley.

—, J. Ray-Mukherjee, N. D’Adesky, D. Nesbeth \& S. Sistla. 2014. The evolutionary ecology and genetics of stress resistance syndrome (SRS) traits: revisiting Chapin, Autumn and Pugnaire (1993). Pp.201-226.In: N. Rajakaruna, R. S. Boyd \& T. B. Harris (eds.), Plant ecology and evolution in harsh environments. Nova Science Publishers, New York.

Wallace, D. R. 1983. The Klamath Knot. University of California Press, Berkeley.

Westerbergh, A. \& A. Saura. 1992. The effect of serpentine on the population structure of Silene dioica (Caryophyllaceae). Evolution 46: 1537-1548.

Widmer, A., C. Lexer \& S. Cozzolino. 2009. Evolution of reproductive isolation in plants. Heredity 102: 31-38.

Williams, J. L., R. E. Snyder \& J. M. Levine. 2016. The influence of evolution on population spread through patchy landscapes. American Naturalist 188: 15-26.

Wright, J. W. \& M. L. Stanton. 2007. Collinsia sparsiflora in serpentine and nonserpentine habitats: Using F2 hybrids to detect the potential role of selection in ecotypic differentiation. New Phytologist 173: 354-366.

\& M. L. Stanton. 2011. Local adaptation in heterogeneous landscapes-reciprocal transplant experiments and beyond. Pp. 155-180. In: S.P. Harrison \& N. Rajakaruna (eds.), Serpentine: the evolution and ecology of a model system. University of California Press, Berkeley.

Wright, K. M., D. Lloyd, D. B. Lowry, M. R. Macnair \& J.H. Willis. 2013. Indirect evolution of hybrid lethality due to linkage with selected locus in Mimulus guttatus. PLOS Biology 11: e1001497.

Wu, C. A., D. B. Lowry, L. I. Nutter \& J. H. Willis. 2010. Natural variation for drought-response traits in the Mimulus guttatus species complex. Oecologia, 162: 23-33.

Wu, L., A. D. Bradshaw \& D. A. Thurman. 1975. The potential for evolution of heavy metal tolerance in plants. I. The rapid evolution of copper tolerance in Agrostis stolonifera. Heredity 34: 165-178.

Yakimowski, S.B. \& L.H. Rieseberg. 2014. The role of homoploid hybridization in evolution: A century of studies synthesizing genetics and ecology. American Journal of Botany 101: 1247-1258.

Yost, J. M., T. M. Barry, K. M. Kay \& N. Rajakaruna. 2012. Edaphic adaptation maintains the coexistence of two cryptic species on serpentine soils. American Journal of Botany 99: 890-897. 